Article

\title{
Land Use, Land Cover Change and Sustainable Intensification of Agriculture and Livestock in the Amazon and the Atlantic Forest in Brazil
}

\author{
Júlia Graziela da Silveira ${ }^{1}$ (D), Sílvio Nolasco de Oliveira Neto ${ }^{1}\left(\mathbb{D}\right.$, Ana Carolina Barbosa do Canto ${ }^{2}$, \\ Fernanda Figueiredo Granja Dorilêo Leite ${ }^{3}{ }^{\mathbb{D}}$, Fernanda Reis Cordeiro ${ }^{4}$, Luís Tadeu Assad ${ }^{5}$, \\ Gabriela Cristina Costa Silva ${ }^{1}$, Renato de Oliveira Marques ${ }^{5}$, Melissa Silva Leme Dalarme ${ }^{6}(\mathbb{D})$, \\ Isabel Gouvea Maurício Ferreira ${ }^{7}$, Marcela Cardoso Guilles da Conceição 8 \\ and Renato de Aragão Ribeiro Rodrigues $3,6,7,8, *$ (D)
}

check for updates

Citation: Silveira, J.G.d.; Oliveira Neto, S.N.d.; Canto, A.C.B.d.; Leite, F.F.G.D.; Cordeiro, F.R.; Assad, L.T.; Silva, G.C.C.; Marques, R.d.O.; Dalarme, M.S.L.; Ferreira, I.G.M.; et al. Land Use, Land Cover Change and Sustainable Intensification of Agriculture and Livestock in the Amazon and the Atlantic Forest in Brazil. Sustainability 2022, 14, 2563. https://doi.org/10.3390/ su14052563

Academic Editors: Marc A. Rosen, Changhe LU and Wenjiao Shi

Received: 30 December 2021 Accepted: 18 February 2022 Published: 23 February 2022

Publisher's Note: MDPI stays neutral with regard to jurisdictional claims in published maps and institutional affiliations.

Copyright: () 2022 by the authors Licensee MDPI, Basel, Switzerland. This article is an open access article distributed under the terms and conditions of the Creative Commons Attribution (CC BY) license (https:// creativecommons.org/licenses/by/ $4.0 /)$.
1 Forest Engineering Department, Federal University of Viçosa, Avenida Peter Henry Rolfs, Viçosa 36570-900, MG, Brazil; juliagrazielasilveira@gmail.com (J.G.d.S.); snolasco@ufv.br (S.N.d.O.N.); gbcristina.silva@gmail.com (G.C.C.S.)

2 Sustainable Development Center, University of Brasília, Darcy Ribeiro Campus, Asa Norte, Brasília 70904-970, DF, Brazil; anacanto@id.uff.br

3 Geochemistry Department, Federal Fluminense University, Rua Mario Santos Braga, Niterói 24020-140, RJ, Brazil; fernandafgdleite@gmail.com

4 Laboratory of Technology and Business Management, School of Engineering, Federal Fluminense University, Rua Passo da Pátria, Niterói 24210-240, RJ, Brazil; fereis.cordeiro@gmail.com

5 Brazilian Institute of Development and Sustainability (IABS), Brasília 71610-015, DF, Brazil; assadmar@iabs.org.br (L.T.A.); renato@iabs.org.br (R.d.O.M.)

6 Embrapa Soils, Rio de Janeiro 22460-000, RJ, Brazil; melissa.dalarme@embrapa.br

7 ICLF Network, Brasília 70381-520,DF, Brazil; isabelferreira@redeilpf.org.br

8 Climate Network, Brasília 12227-010, DF, Brazil; marcelaguilles.clima@gmail.com

* Correspondence: renato.rodrigues@embrapa.br

\begin{abstract}
The Amazon and the Atlantic Forest are Brazilian biomes that suffered an intense land use and land cover change, marked by the loss of native forest and expansion of agriculture and livestock. This article aims to analyze land use and land cover change history and to propose a sustainable alternative for agriculture and livestock as an opportunity for rural development in these biomes. The statistics of the platform from the Annual Mapping Project for Land Use and Land Cover in Brazil (MapBiomas) were used in an annual historical series from 1985 to 2020. The analysis of land use and land cover changes indicates that the Amazon native forest was reduced by 44.53 million hectares (Mha), while pasture, agriculture and planted forest increased by 38.10, 6.06 and 0.26 Mha, respectively, over the 35 years (1985 to 2020). In the Atlantic Forest, for the same period, forest and pasture reduced by 0.99 and 11.53 Mha, respectively, while agriculture expanded by 8.06 Mha and planted forest by 2.99 Mha. Sustainable land use strategies, such as the Integration Crop-Livestock-Forest (ICLF), can support the increase in agricultural production while recovering and preserving the environment. Policies and programs should consider regional particularities and barriers for more significant adoption of this strategy.
\end{abstract}

Keywords: deforestation; sustainable development; Agroforestry; integration crop-livestock-forestry

\section{Introduction}

Approximately 70\% of the earth's surface has already undergone some type of anthropogenic alteration, converting native forests for agricultural production, infrastructure, and urban use [1]. These changes reduce the performance of agricultural and livestock activities [2], which can affect food availability [3] for a growing global population [4].

Land use time series show that Brazil lost 71 Mha of native forest over 34 years, due to the expansion of pasture areas (by $46 \%$ ) and agricultural areas (by 172\%) [5]. In this setting, 
we highlight the Amazon and Atlantic Forest biomes as they host intense activities in these sectors, representing $81 \%$ of agricultural production [6] and $57 \%$ of the pasture herd of Brazil [7].

These biomes have rich and diverse species, including endemic ones [8-11]. The Amazon has the most extensive remaining tropical forests in the world (approximately $60 \%$ ), making it a biodiversity hotspot [12], and essential in the mitigation of climate change [13]. However, the expansion of livestock and agriculture, mainly in the southern and eastern regions [14] has accelerated the loss of native forest [15].

The Atlantic Forest is represented by landscapes of small forest fragments marked by deforestation [16], where only $12 \%$ of native forest cover remains [17]. Approximately $70 \%$ of the Brazilian population lives in this biome [18], which has driven massive industrialization and agricultural expansion, replacing forest areas [19]. This biome is considered one of the three hotspots most vulnerable to global warming [20].

The Amazon is at serious risk due to the proportion of native forest, creating direct and indirect incentives for landowners and land grabbers to advance illegal deforestation [21], driven mainly by the expansion of agricultural and pasture areas [22]. Meanwhile, with small, isolated forest patches $[23,24]$, the Atlantic Forest is on the verge of ecosystem collapse and catastrophic loss of biodiversity due to the magnitude and extent of deforestation [25].

This critical setting of intense changes in land use and land cover is still poorly investigated at present, especially in the Atlantic Forest [26]. Understanding how land use changes over time and space and how this affects landscape structure are essential factors in managing ecosystem services and species conservation, neutralizing threats to biodiversity [27-30]. Then, we should prevent and minimize undesirable impacts, such as reducing agricultural productivity [31]. Exploring this landscape change through a land-use historical series can provide decision-making and support land-use planning to strengthen social, economic, and environmental development [5].

A set of strategies is necessary to reconcile the need to provide livelihoods for the residents of the regions, food for the population and conservation of the native forests that still remain [27]. New land use practices, agricultural and livestock strategies and technologies that support sustainable intensification can foster environmental conservation without compromising food production [32-34]. In this context, understanding the temporal dynamics of land use and land cover changes and current land use becomes an essential factor in overcoming sustainability challenges in the Amazon and Atlantic Forest.

Thus, this study aims to present an analysis of land use and land cover in the Amazon and Atlantic Forest, in a historical series from 1985 to 2020 through available data from MapBiomas, and with that to identify the main changes that occurred in these 35 years. Subsequently, we identified the main drivers of these changes through the literature and proposed a sustainable strategy, analyzing the main barriers to its adoption.

\section{Materials and Methods}

\subsection{Study Area}

The selected study areas were the Brazilian Amazon and Atlantic Forest biomes (Figure 1). The Amazon extends to the states of Acre, Amapá, Amazonas, Pará, Rondônia, Roraima, Tocantins, Mato Grosso and Maranhão, comprising 558 municipalities and occupying an area of 5 million square kilometers. The Atlantic Forest extends from Rio Grande do Norte to Rio Grande do Sul, comprising 3082 municipalities and an area greater than 1.1 million square kilometers [35]. 


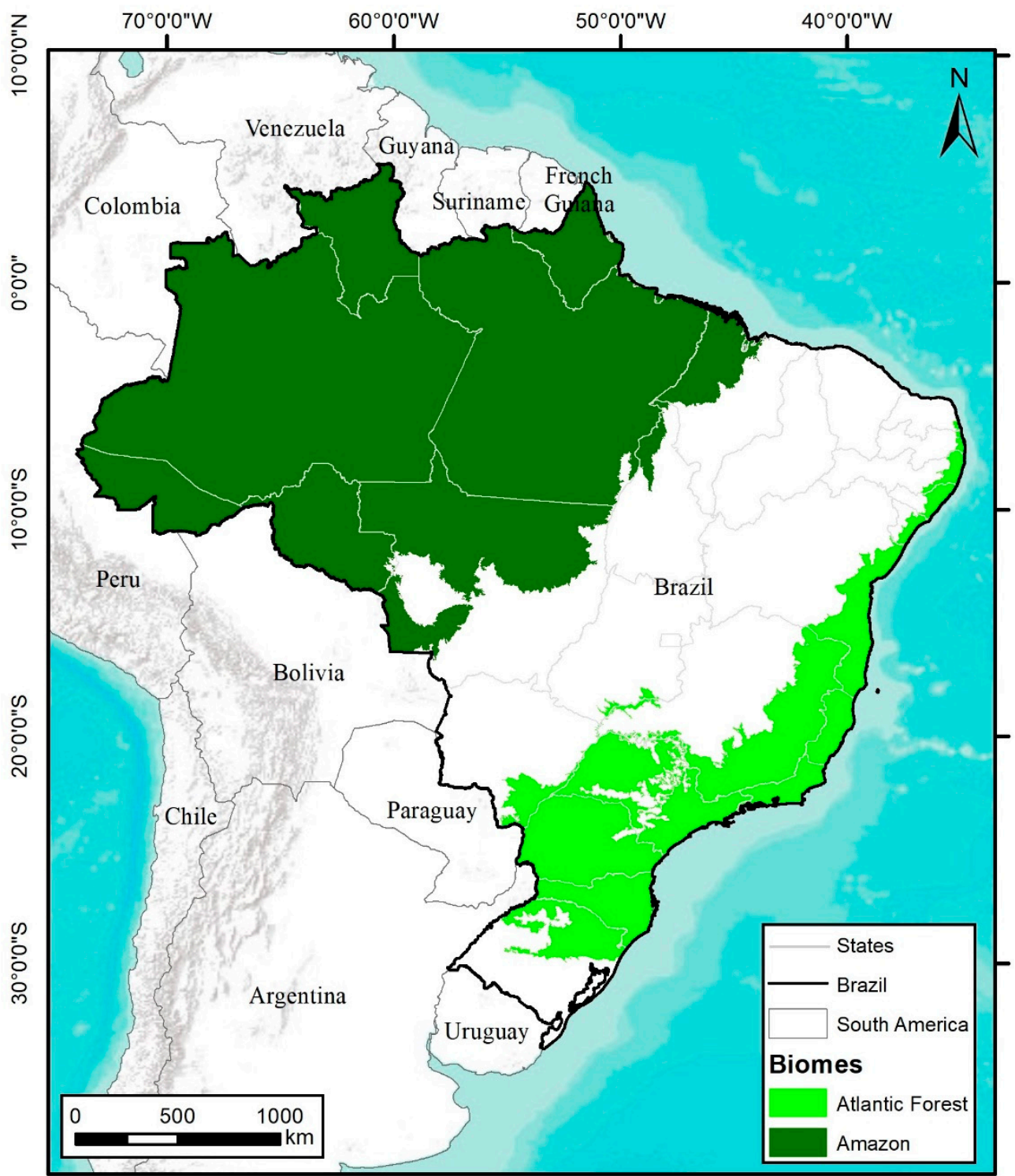

Figure 1. Map of Brazil, with the Amazon biome colored in dark green and the Atlantic Forest in light green. Country and biome boundary data from IBGE [36].

\subsection{Spatial and Temporal Trends in Land Use and Land Cover}

We used data from the sixth collection of the MapBiomas platform, in an annual historical series from 1985 to 2020 [37]. The data are generated from the automated processing of Landsat 5 Thematic Mapper ${ }^{\mathrm{TM}}$, Landsat-7 Enhanced Thematic Mapper Plus (ETM+) and Landsat-8 sensors e Operational Land Imager and Thermal Infrared Sensor (OLI-TIRS). The Landsat imagery collections with $30 \mathrm{~m}$ pixel resolution were accessible via Google Earth Engine and produced by NASA and USGS [37]. The general accuracy for the Amazon biome was $96.6 \%$, with $2.4 \%$ allocation disagreement and $1.0 \%$ area disagreement [38]. In the Atlantic Forest biome $85.5 \%$ of general accuracy, $8.3 \%$ of allocation disagreement and $6.2 \%$ of area disagreement [38].

The land cover and land use classification scheme by MapBiomas is a hierarchical system compatible with the classification systems of the Food and Agriculture Organization (FAO) [39] and Brazilian Institute of Geography and Statistics (IBGE) [40], which have different levels and classes. We considered six land use and land cover classes, according to level 2 of the land cover and use classification system for MapBiomas in Brazil [41], as follows: (1) Native forest (includes forest formation, savanna formation, mangrove and 
wooded restinga); (2) pasture; (3) agriculture (includes temporary crop and perennial crop); (4) forest plantation; (5) mosaic of agriculture and pasture and; (6) other land uses (includes non-forest natural formation, non-vegetated area, water and non-observed).

Below is a brief description of each land use and land cover classes, according to MapBiomas [41] and Souza et al. [5].

1. Native forest: land cover with predominance of tree species with continuous highdensity canopy; and/or with a tree layer varying in density, distributed over a continuous shrub-herb layer; and/or dense and always green, often flooded by the tide;

2. Pasture: referring to pasture areas, natural or planted, linked to livestock activity;

3. Agriculture: agricultural cultivation areas, occupied with temporary crops (soybean, sugarcane, rice, and other temporary crops) and perennial crops (coffee, citrus, other perennial crops);

4. Planted forest: area with tree species cultivated for commercial purposes;

5. Mosaic of agriculture and pasture: areas of agricultural use where we could distinguish between pasture and agriculture, found only in the Atlantic Forest;

6. Other land use: several uses outside the interest of this research were grouped. This use was used only to identify the territorial proportion for the years 1985 to 2020 and in the constructed map. It was not considered in the annual historical series.

According to Martinez et al. [42], land use is related to the human interactions with the land surface, while land cover is related to the natural earth's surface characteristics. The description of each class can be checked in detail in MapBiomas General "Handbook" [41].

The land use and land use and cover change during the years 1985 and 2020 were performed obtaining:

- Quantification of the area in Mha of each land use and land cover classes for 1985 and 2020. These values were obtained from MapBiomas database.

- Percentage of territorial occupation (\%) of each land use and land cover classes for 1985 and 2020 (Equation (1)):

$$
\text { Territorial occupation }(\%)=\left(\frac{\text { area of the verified class }}{\text { total area of the biome }}\right) 100
$$

- Difference class area (hectares) between the years (1985 and 2020) to verify the increase or decrease in a specific class in territorial occupation through Equation (2) [43]:

Land use and land cover change $($ Mha $)=$ final year area - initial year area

We also analyzed land use and the rate of land use change annually, from 1985 to 2020, through:

- Quantification of the area (Mha) of each land use and land cover classes (except "other uses") for all selected years (1985 to 2020). These values were obtained from MapBiomas database.

- $\quad$ Annual land use and land cover change rate (\%) for all selected years (1985 to 2020) in each land use and cover classes (except "other uses"), through Equation (3) [43]:

Annual land use and land cover change rate $(\%)=\left(\frac{(\text { Area of current year }- \text { Area of previous year })}{\text { Area of previous year }}\right) 100$

When the results were negative, it meant a decrease in the area and the territory percentage. The results were positive when there was no negative sign, and there was an increase in the land use class.

A simple linear model (Equation (4)) was fitted for each land use and land cover class, with the relation of the area as a function of time. These adjustments were analyzed through 
the significance of the $\beta 1$ parameter $(\alpha=0.05)$ to verify the trend of each land use and land cover over the observed interval (1985 to 2020) [44-47]:

$$
y=\beta 0+\beta 1 x+\varepsilon
$$

where: $y=$ area (Mha); $\beta 0$ and $\beta 1=$ regression parameters; $x=$ year; $\varepsilon=$ random error.

The discussion and the comprehension of land use and land cover changes over the analyzed period were based on the literature, and historical social and political events that triggered the land use and land cover change.

To help with the discussion, we created a map representing the land use and land cover changes in the study areas in 1985 and 2020, presented as a result. Thus, an analysis was performed using ArcGIS software tools, combining the layers of information over the different years.

This paper also explored possible actions for the future in biomes through a literaturebased discussion, which allows better identification of necessary tools for land use aiming for sustainable development in the Amazon and Atlantic Forest biomes

\subsection{Animal Stocking Rate over 35-Year Period}

Data from the livestock herd time series were employed through the Municipal Livestock Survey (PPM), obtained by the Brazilian Institute of Geography and Statistics (IBGE) from 1985 to 2018, for all municipalities belonging to the Atlantic Forest and the Amazon [7]. These data provide the basis for analyzing the livestock head number and animal stocking rate. For this analysis, all animals managed in pastures were selected: cattle, horses, buffaloes, goats, and sheep. The information was extracted at the municipality level and grouped at the biome level annually. The PPM data were obtained through consultations with qualified informants in the production chain, governments, and other market agents, which resulted in estimates based on technical knowledge and administrative records. Concerning cattle information, IBGE also considers the vaccination campaign against Footand-Mouth Disease in the municipality. The livestock herd is counted regardless of type, sex, age, breed, or purpose [48].

The temporal analysis of the livestock herd was based on the total head in millions (M heads) obtained from PPM. The stocking rate (head ha ${ }^{-1}$ ) was calculated annually (1985 to 2020), based on Equation (5):

$$
\text { Animal stocking rate }\left(\text { head } \mathrm{ha}^{-1}\right)=\left(\frac{\text { Total animal head }}{\text { total pasture area }}\right)
$$

\section{Results}

\subsection{Spatial and Temporal Trends in Land Use and Land Cover}

\subsubsection{Amazon Biome}

The Brazilian Amazon was represented originally by an area of 420.77 Mha. Of this total, in 1985, native forest represented the primary land use, covering $89.02 \%$, with 374.57 Mha. The class "other land use", including non-forest natural formation, nonvegetated area, water, and those not observed, covered 6.55\% (27.58 Mha) of the biome. Pasture reached about $4 \%$ of the territory in that same year, occupying $18.54 \mathrm{Mha}$. The minority classes of land use in terms of extension were agriculture ( $0.08 \mathrm{Mha})$, followed by planted forest $(0.003 \mathrm{Mha})$, which together represented $0.02 \%$ of the territory (Table 1$)$. 
Table 1. Total area (Mha) and territorial proportion (\%) of different land use and land cover classes for the years 1985 and 2020. The land use and land cover changes (Mha) consider the period of 35 years (between 1985 and 2020) for each land use and cover in the Amazon biome.

\begin{tabular}{cccccc}
\hline \multirow{2}{*}{ Land Use and Land Cover } & \multicolumn{3}{c}{$\mathbf{1 9 8 5}$} & \multicolumn{3}{c}{$\mathbf{2 0 2 0}$} & Land Use Change (Mha) \\
\cline { 2 - 5 } & Area (Mha) & $\begin{array}{c}\text { Territorial } \\
\text { Proportion (\%) }\end{array}$ & Area (Mha) & $\begin{array}{c}\text { Territorial } \\
\text { Proportion (\%) }\end{array}$ & \\
\hline 1. Native forest & 374.57 & $89.02 \%$ & 330.03 & $78.44 \%$ & -44.53 \\
2. Pasture & 18.54 & $4.41 \%$ & 56.65 & $13.46 \%$ & 38.10 \\
3. Agriculture & 0.08 & $0.02 \%$ & 6.13 & $1.46 \%$ & 0.06 \\
4. Forest plantation & 0.003 & $0.001 \%$ & 0.27 & $0.063 \%$ & 0.26 \\
6. Other land use & 27.58 & $6.55 \%$ & 27.69 & $6.58 \%$ & \\
Total & 420.77 & $100.00 \%$ & 420.77 & $100.00 \%$ & \\
\hline
\end{tabular}

A total of 44.53 Mha of native forest were converted into 38.10 Mha of pasture. The other 6.43 Mha of forest lost were converted into agriculture (6.06 Mha) and planted forest (0.26 Mha) areas. Thus, in 2020, the native forest represented $78.44 \%$ (330.03 Mha) of the territory, while the pasture covered $13.46 \%$ (56.65 Mha) of the total area, the second-largest land use in the Amazon. In 1985, agriculture represented only $0.02 \%$ of the territory, and $1.46 \%$ (6.13 Mha) of the territory in 2020. The planted forest covered $0.06 \%(0.27 \mathrm{Mha})$ of the territory in 2020, while "other land use" represented 6.58\% (27.69 Mha), and was the class that achieved the lowest gains in the period (Table 1).

Observing the annual historical series from 1985 to 2020 (Figure 2A), all land uses evidence the significance of the parameter $\beta 1(\alpha<0.05)$, which shows a declining trend (dashed line in Figure 2A) of the native forest over these years, while the other uses (pasture, agriculture, planted forest) increased.
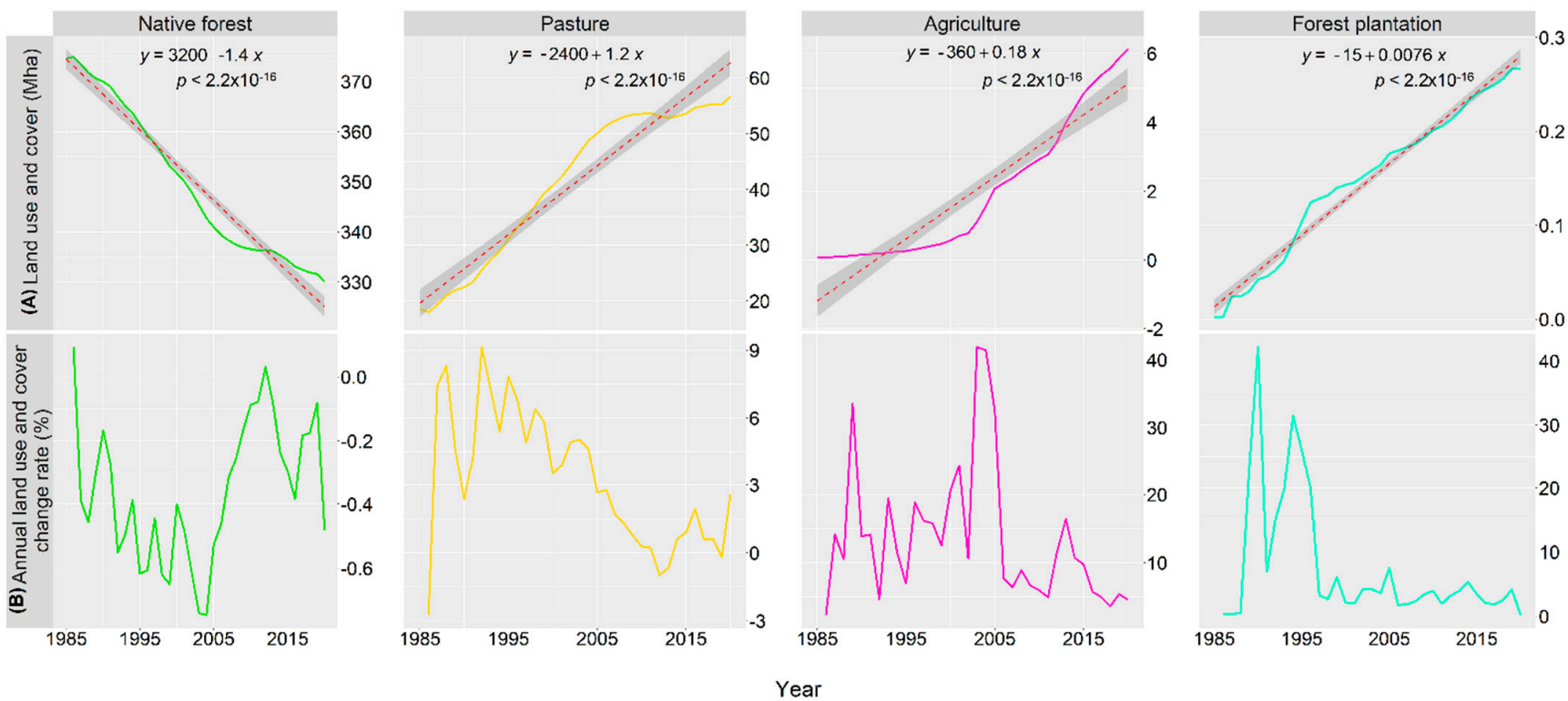

Figure 2. Land use and land cover (A) for the primary classes for Amazon, where the dashed line refers to the simple linear regression. Annual land use and land cover change rate (B), where the values above zero represent an area increase, and values below zero represent loss of area when compared to the previous year. Land use and land cover data refer to MapBiomas [37].

The annual losses of native forest ranged from $-0.08 \%$ to $-0.75 \%$. The conversion occurred mainly between 1991 and 2005, with mean annual losses of $-0.56 \%$ ( -2.00 Mha per year), equivalent to a total reduction of $-28.02 \mathrm{Mha}$ of land (Figure 2A). In this same period of significant loss of native forests, pasture increased by $26.62 \mathrm{Mha}$, with mean annual gains of $5.58 \%$ (Figure $2 \mathrm{~A}, \mathrm{~B}$ ). 
After this period, the rate of loss of native forest area decreased between 2005 and 2011 , with a mean of $-0.23 \%$ per year, until reaching the lowest rate recorded in 2012 . However, the levels of forest loss returned to increase and surpassed -1.60 Mha in the $2019-2020$ period ( $-0.48 \%$ of the territory with native forest) (Figure $2 \mathrm{~A}, \mathrm{~B})$. The loss of native forest was mainly for pasture, which increased by $1.43 \mathrm{Mha}$ in that period (Figure 2A).

Overall, the land use class pasture's area increase ranged from $0.22 \%$ to $9.14 \%$. This class had few territorial losses over the 35 years, but it decreased $(-2.73 \%,-0.51 \mathrm{Mha})$ in the 1985-1986 period, when mainly replaced by agriculture. The increases were mainly recorded from 1991 to 1999 (mean annual of 6.69\% per year) (Figure 2B). In that same period, the average area gain was 1.98 Mha per year.

Agriculture showed an increase in area over the 35 years (Figure 2A,B). The period 2002 to 2005 represented the biggest increase, with an average gain of $38.59 \%$ per year (total increase of $1.29 \mathrm{Mha}$ ). The sum of area gained in these periods represented $22 \%$ of the entire increase. The slowest pace of agriculture area gain was observed between 2005 and 2011, and 2015 and 2020, with an annual average of 5.88\% (Figure 2B).

The same pattern of the land use class of agriculture was observed in the planted forest, with an increase throughout 1985 to 2020 (Figure 2A,B). However, in terms of extension, as shown in Table 1, the planted forest area is still a minority. During the period of 1989-1990 that land use had the highest rate of increase, with $42.18 \%$ (Figure 2B), representing an increase of 0.01 Mha (Figure 2A). From 1993 to 1995, the territorial increase was an average of $28.75 \%$ per year (total increase of $0.04 \mathrm{Mha}$ ). Overall, after 1996, the annual rate of increase was lower (average of $3.24 \%$ per year) compared to previous years. In the period of 2019-2020 it was observed to have the lowest annual increase rate $(0.21 \%)$.

In the last evaluated period (2019-2020), native forest had a total area loss of $-0.84 \%$, while pasture, agriculture and planted forest grew together by $7.35 \%$, representing an increase of 1.70 Mha converted from the other uses.

\subsubsection{Atlantic Forest}

The Brazilian Atlantic Forest is represented by a total area of 110.66 Mha. In 1985, this territory was covered mainly by pasture areas, which constituted $36.14 \%$ (39.99 Mha) of the area, followed by native forest, which occupied 29.74\% (32.91 Mha). The agriculture and pasture mosaic is the third largest land use class, representing $17.40 \%$ (19.26 Mha), followed by agriculture $(9.68 \%, 10.71 \mathrm{Mha})$ and "other land uses" (6.28\%, 6.95 Mha). The minority class of land use regarding extension was planted forest, which represented only $0.77 \%$ (0.85 Mha) of the territory in that same year (Table 2$)$.

Table 2. Total area (Mha) and territorial proportion (\%) of different land use and land cover classes for the years 1985 and 2020. The land use and land cover change (Mha) consider the period of 35 years (between 1985 and 2020) for each land use and cover in the Atlantic Forest biome.

\begin{tabular}{|c|c|c|c|c|c|}
\hline \multirow[b]{2}{*}{ Land Use and Land Cover } & \multicolumn{2}{|c|}{1985} & \multicolumn{2}{|c|}{2020} & \multirow[b]{2}{*}{ Land Use Change (Mha) } \\
\hline & Area (Mha) & $\begin{array}{c}\text { Territorial } \\
\text { Proportion (\%) }\end{array}$ & Area (Mha) & $\begin{array}{c}\text { Territorial } \\
\text { Proportion (\%) }\end{array}$ & \\
\hline 1. Native forest & 32.91 & $29.74 \%$ & 31.92 & $28.84 \%$ & -0.99 \\
\hline 2. Pasture & 39.99 & $36.14 \%$ & 28.46 & $25.72 \%$ & -11.53 \\
\hline 3. Agriculture & 10.71 & $9.68 \%$ & 18.78 & $16.97 \%$ & 8.06 \\
\hline 4. Forest plantation & 0.85 & $0.77 \%$ & 3.84 & $3.47 \%$ & 2.99 \\
\hline $\begin{array}{l}\text { 5. Mosaic of Agriculture and } \\
\text { Pasture }\end{array}$ & 19.26 & $17.40 \%$ & 20.14 & $18.20 \%$ & 0.89 \\
\hline 6. Other land uses & 6.95 & $6.28 \%$ & 7.53 & $6.80 \%$ & 0.58 \\
\hline Total & 110.66 & $100.00 \%$ & 110.66 & $100.00 \%$ & \\
\hline
\end{tabular}

The land use and land cover changes were mainly driven by a loss of pasture and native forest area and a gain of area in agriculture and planted forest area (Figure 3A) over the 35 years, resulting in a reduction of -11.53 Mha of pasture and -0.99 Mha of native 
forest, which were converted into 8.06 Mha of agriculture, 2.99 Mha of planted forest, and 1.47 Mha from the sum of agriculture, pasture, and other land uses (Table 2).
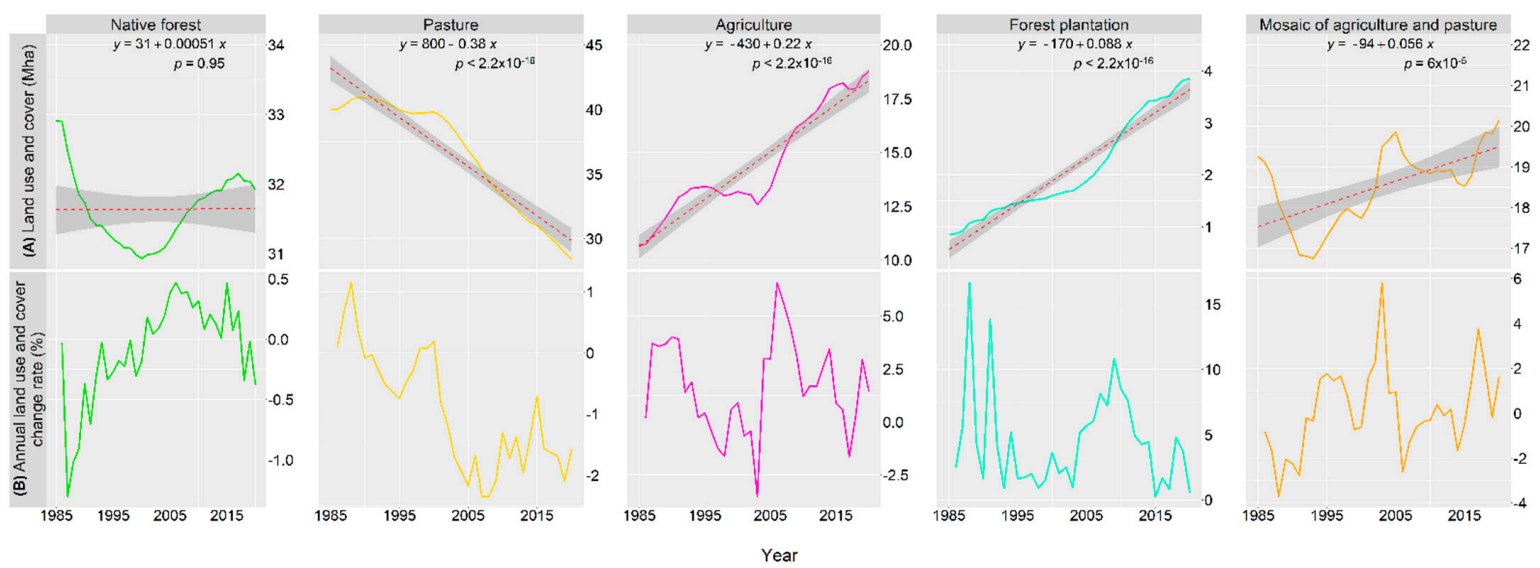

Figure 3. Land use and land cover (A) for the primary classes for Atlantic Forest, where the dashed line refers to the simple linear regression. Annual land use and land cover change rate (B), where the values above zero represent an area increase, and values below zero represent a loss of area when compared to the previous year. Land use and land cover data refer to MapBiomas [37].

In 2020, the native forest still represented the primary land use in this biome $(28.84 \%$, $31.92 \mathrm{Mha})$, followed by pasture $(25.72 \%, 28.46 \mathrm{Mha})$, agriculture and pasture mosaic $(18.20 \%, 20.14 \mathrm{Mha})$, agriculture $(16.97 \%, 18.78 \mathrm{Mha})$, other land uses $(6.80 \%, 7.53 \mathrm{Mha})$ and planted forest $(3.47 \%, 3.84 \mathrm{Mha})$. Even though the native forest represents the primary land use, it is essential to highlight that there were losses, but in a smaller proportion than the pasture and therefore it became the most representative class (Table 2).

Observing the annual historical series from 1985 to 2020 (Figure 3A), except for native forest, all classes show the significance of the $\beta 1$ parameter $(\alpha<0.05)$, which indicates that the native forest area fluctuated over the 35 years, with mean values of $31 \mathrm{Mha}$. The pasture showed a trend (dashed line in Figure $3 \mathrm{~A}$ ) of territorial loss, meanwhile agriculture, planted forest and agriculture and pasture mosaic showed a gain trend.

In the analyzed time interval, the native forest class was converted mainly from 1986 to 1991, with total area losses of $-4.39 \%$. During that period, 1.39 Mha were converted mainly into agriculture, planted forest, and other land uses. On the other hand, from 2000 to 2017, the native forest had a mean annual area growth of $0.23 \%$ (1.23 Mha total). However, native forest areas were again converted into other uses from 2017 to 2020, with accumulated losses of $-0.74 \%$ (Figure $3 \mathrm{~A}, \mathrm{~B}$ ).

In the pasture class, there were few signs of annual expansion of the area. This increase was observed only from 1985 to 1989, with a total gain of 2.32\% (0.93 Mha), and from 1997 to 2000 , with an increase of $0.35 \%$ ( $0.93 \mathrm{Mha}$ ). In these periods, the pasture occupied mainly areas of native forest and agriculture and pasture mosaic (Figure $3 \mathrm{~A}, \mathrm{~B}$ ).

From 2000 onwards, pasture areas shrunk on average $-1.66 \%$ per year and resulted in the conversion of -11.36 Mha (Figure 3A,B). Overall, from 2000 to 2003, pasture was mostly converted to planted forest and agriculture and pasture mosaic. From 2000 to 2003, pasture was mainly converted into planted forest and agriculture and pasture mosaic. From 2003 to 2015, pasture areas were mainly replaced by agriculture and planted forest, and, later, the mosaic of agriculture and pasture also increased.

The agriculture class recorded loss periods, which resulted in $-9.55 \%$ of lost area $(-1.34$ Mha in total), mainly identified in 2002-2003 (-3.51\%). The lost areas were mainly converted into agriculture and pasture mosaic and planted forests. These periods were offset by the territorial gain from agriculture, which occurred in most of the years analyzed and totaled 9.40 Mha (mean annual of $2.39 \%$ ). 
Area gains from agriculture were more intense from 1986 to 1991 (average of 3.77\% per year) and from 2005 to 2009 (average of 4.95\% per year). The gains in these periods resulted in a total increase of 5.04 Mha, relative to $62 \%$ of the total area gain in the 35-year interval (Figure 3A,B).

Although the territorial representation of forest plantations is the lowest among the land uses, this was the only class with recurrent increases throughout the entire evaluated period. The 1987-1988 and 1990-1991 periods were the primary peaks of planted forest area increase, with $16.64 \%$ and $13.83 \%$, respectively (Figure $3 \mathrm{~B}$ ). This increase resulted in 0.31 Mha of new planting areas. The 2006-2011 period recorded a mean annual increase of $8.46 \%$ (mean annual of $0.20 \mathrm{Mha}$ ). The lowest rate of planted forest increase was recorded in the 2014-2015 period, with $0.28 \%$ (Figure 3A,B).

The mosaic class of agriculture and pasture area decreased, on average, $-1.20 \%$ per year, identified mainly from 1987 to 1991 (mean annual of $-2.69 \%$ ). The area increase ranged from 5.81\% (2002-2003) to 0.17\% (2012-2013) (Figure 3B).

In the 2019-2020 period, native forest and pasture had total area losses of $-2.42 \%$ (-0.61 Mha), while agriculture, planted forest, and agriculture and pasture mosaic grew together (3.62\%) (Figure 3A,B).

\subsubsection{Land Use and Land Cover Overview}

When considering the spatial distribution of classes in 1985 and 2020, we can see the main expansion regions for each use, as shown in Figure 4 (1985 and 2020). In the Amazon, the most evident changes at this map scale are the expansion of pastures covering formerly native forest areas (Figure 4). We noticed that pasture expanded throughout the entire biome, even with the highest concentrations to the east and southwest. In contrast, agriculture areas were concentrated in the southern region of the Amazon bordering with the Cerrado biome.

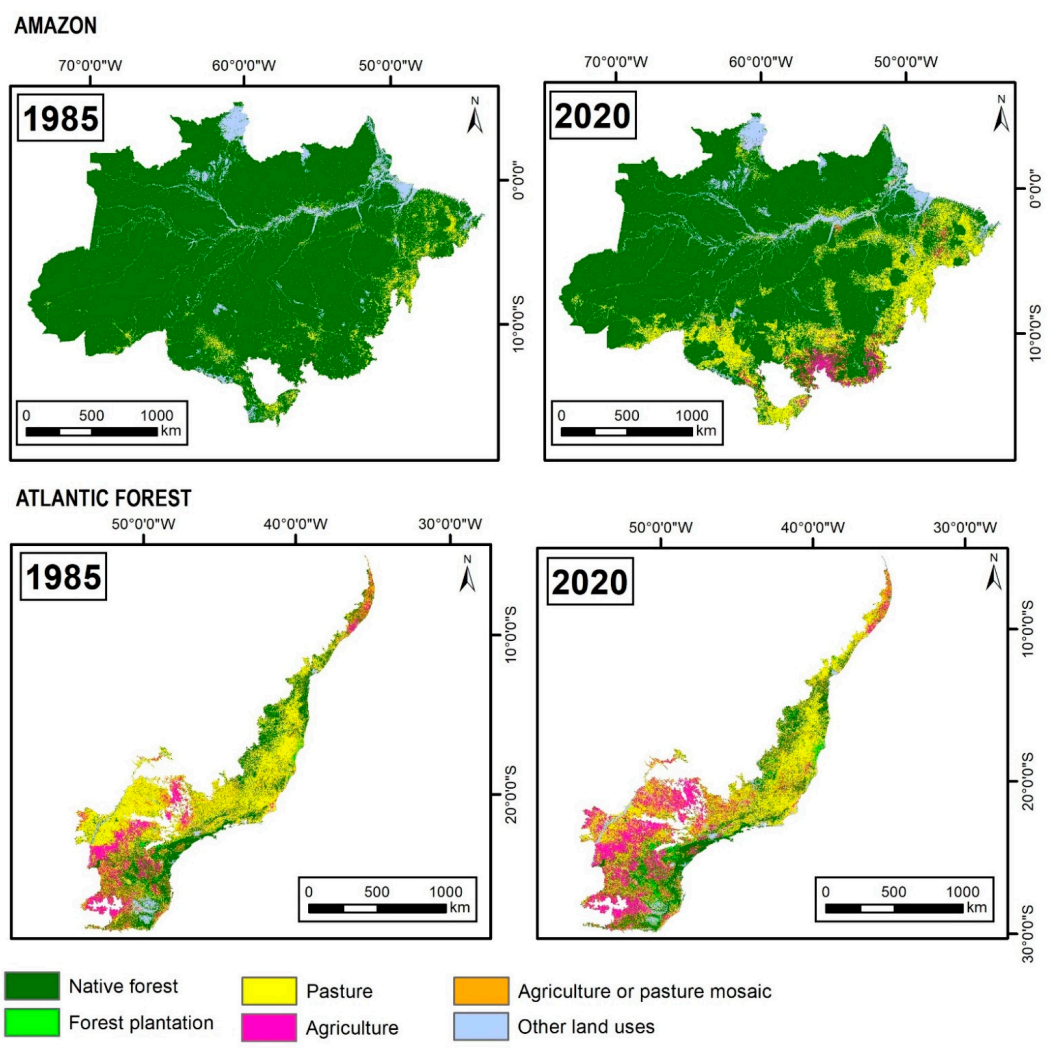

Figure 4. Land use and land cover observed in 1985 and 2020 in the Amazon and Atlantic Forest biomes. Land use and land cover are provided from MapBiomas [37], country and biome boundary data from IBGE [36]. 
The Atlantic Forest has an older occupation history. In 1985, we already observed the territorial extension of pastures, which were gradually replaced by agricultural areas (2020), mainly in the southwest region of the biome (Figure 4).

\subsection{Animal Stocking Rate over 35 Years}

The increase in the number of livestock in million (M) heads in 35 years (1985-2020) outpaced the growth of the pasture area, both in the Amazon and the Atlantic Forest (Figure 5).

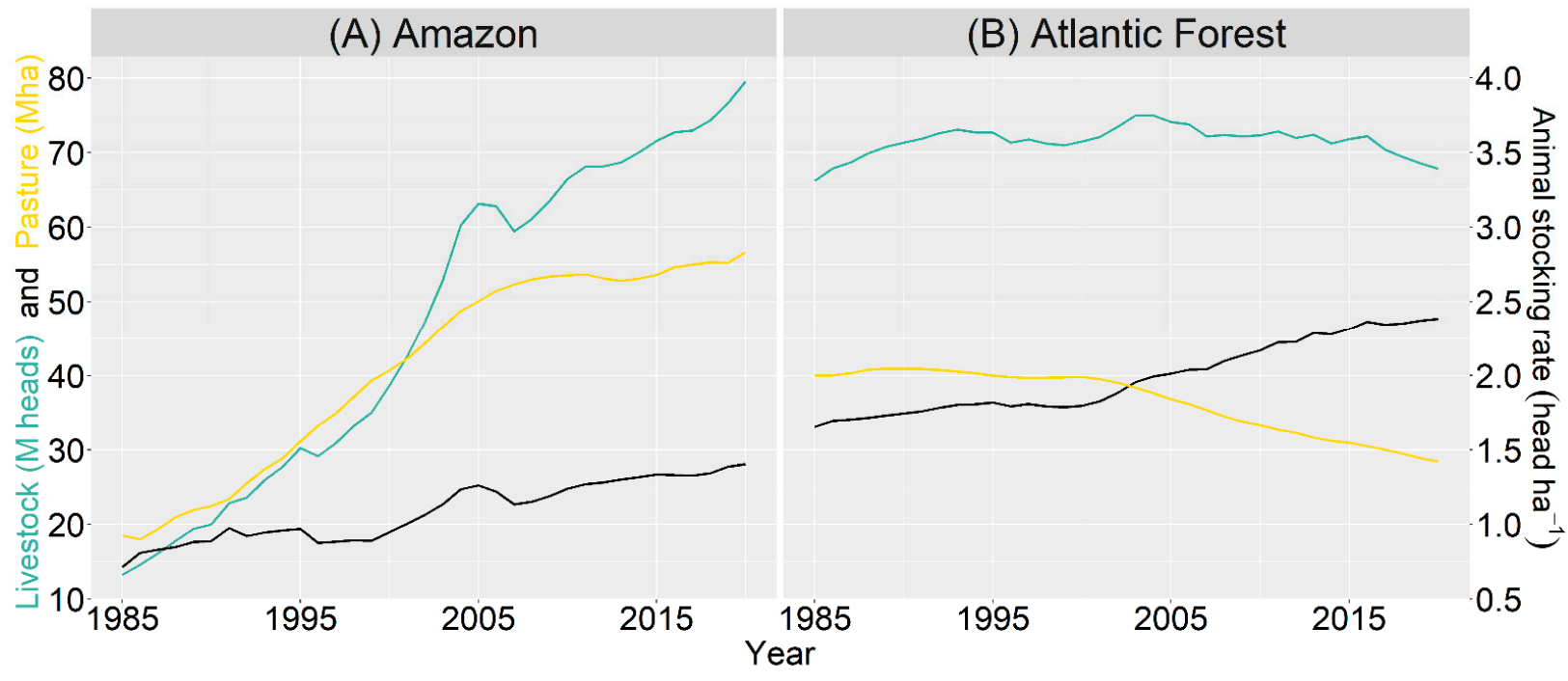

Figure 5. Livestock herd, pasture area and animal stocking rate (relation between the livestock herd and pasture area) for the Amazon (A) and Atlantic Forest (B) biomes.

In the Amazon biome, the livestock went from 13.25 M heads (1985) to 79.57 M heads (2020), a six-fold increase, while the pasture area increased three-fold in the same period. Thus, in the last 35 years, the Brazilian Amazon has increased the stocking rate of its pastures, from 0.71 head ha $^{-1}(1985)$ to 1.40 head ha $^{-1}$ (2020), contributing to the increase in this parameter by $97 \%$ (Figure $5 \mathrm{~A}$ ).

In the Atlantic Forest, while the pasture area shrunk ( $-29 \%$ of area), the livestock increased, from 66.22 M heads (1985) to 67.88 M heads (2020), with an increase of $1.66 \mathrm{M}$ heads in the pasture areas. As a result, the mean stocking rate hiked from 1.66 to $2.39 \mathrm{M}$ heads per hectare of pasture (Figure 5B).

\section{Discussion}

\subsection{Land Use and Land Cover}

\subsubsection{Amazon Biome}

The 1991 to 2005 period recorded the highest native forest loss rates, caused mainly by country's economy transitions, with constant incentives for the migratory flow, tax incentives, expropriation of vacant land for agricultural projects, rural credit, tax exemptions and land concessions for investments in the region, highest rates of loss of native forest, caused mainly by transitions in the country's economy with constant incentive for the migratory flow, tax incentives, expropriation of vacant land for agricultural projects, rural credit, tax exemptions and land concessions for investments in the region [11,49,50]. An increase in the agriculture and livestock area was recorded in the same period and was driven by direct government incentives to meet the growing international demands for soy and beef [51].

After a period of high loss of native forest areas in the Amazon, we observed a slowdown in the deforestation pace from 2005 to 2014, with several actions explaining this event, which include the command-and-control inspection actions by state and federal 
agencies [52-55], the creation of plans such as the "Action Plan for the Prevention and Control of Deforestation in the Legal Amazon" (PPCDAm) [56] and restrictions on credit available to illegal deforesters [57-59], the creation of public lists of properties and municipalities with illegal deforestation [60], the establishment of new protected areas [61] and the moratoriums to eliminate illegal deforestation from production chains for soybeans (e.g., Soybeans Moratorium) and beef (e.g., Meat Conduct Adjustment Agreement) [62-64].

Recently, the deforestation pace has picked up again, particularly in 2019-2020, to convert native forests into agriculture and pasture areas. As predicted by Rodrigues et al. 2019, the reason for this may be directly associated with the exhaustion of some environmental policies $[62,65]$. For example, the anti-environmental discourse of the current Brazilian government [66], which focuses on dismantling environmental structures and legislation [67]. Among several negative actions, the government took an adverse approach to the Amazon Fund, resulting in a loss of US\$1 billion in funds to preserve the Amazon [68,69], besides inciting illegal activities, such as land grabbing, mining, and logging [70].

The Amazon's forest area has been predicted to stabilize at 328 Mha from 2030, considering the regrowth and legal cuts of primary forest [28]. However, measures to prevent illegal deforestation in the Amazon and incentives for more efficient production shall be escalated to achieve this. This same study shows that Brazil could double agricultural areas by 2050, compared to 2010 areas, while pastures could significantly decrease, per the adoption of best practices to increase animal productivity [28].

Livestock is the most important land use in the Amazon, appearing in all regions. At the same time, agriculture is concentrated in the southern region of the biome (Figure 5-Amazon), where a set of infrastructure, accessibility, market, and climatic conditions contribute to its development [65,71-73]. Azevedo Junior et al. [65] observed that the supply chain, logistics, technology, labor, knowledge, and capital are uneven between regions of the Amazon biome, leading to the concentration of agriculture in strategic locations. Although the agricultural area is growing, production has outpaced the other areas, showing more efficient land use. However, the values are still well below their potential. This land use class still contributes approximately one-third of deforestation in the Amazon region, mainly linked to the expansion and appreciation of the agricultural sector in other parts of the country [74].

In a general context, pastures in Brazil, especially in the Amazon, are still extensive, with low inputs and a high degree of degradation and, consequently, low yields [75], because production is based on low input demand, neglecting technologies and property management strategies that could increase productivity [76,77]. Those showing higher productivity are usually accompanied by a drastic increase in the use of inputs and capital [78], which is justified by the fact that $76.3 \%$ of the Amazonian municipalities have hardly any access to production and market factors, and the ones that do generally choose crops [65].

Although the livestock sector has also shown a higher efficiency in the last 35 years, identified here through the animal stocking rate (Figure 5), this occurred slowly. Regardless of the biome, the animal stocking rate in Brazil is 32 to $34 \%$ of its capacity [29].

The production of agricultural commodities is in economies of scale and still subject to an increase in agricultural land in Brazil. Further, extensive production and low efficiency of pastures in the Amazon increasingly pressure the opening of new lands [68,79]. The trend of loss of native forests found in our study calls for new solutions, together with environmental policies, to preserve the biome [62]. Our results support recent calls to prioritize forest protection in promoting sustainable land use in the Amazon [80].

\subsubsection{Atlantic Forest Biome}

The intensive loss of native forests in the Atlantic Forest began before the historical series analyzed in this study. The economic exploitation of different commodities accompanied the loss of native forest (e.g., Pau-Brasil, sugarcane, coffee, and cocoa) [81,82], in parallel with the expansion of the population, urban-industrial spaces and agricultural borders of the country [83]. 
Although the area of native forest evidence periods of territorial gains and losses, in the periods with tendencies towards more significant area reductions (1986 to 1991), 75\% of the charcoal originated from native forest, leading to more significant deforestation [84].

During the second half of the 20th century and the beginning of the 21st century, the native forest area gain occurred mainly in areas with slopes above $20 \%$, unsuitable for agricultural mechanization, irrigated systems, and livestock [85]. In some Atlantic Forest regions, the old pastures used for milk and beef production contributed about 75\% to the new forest areas between 1980 and 2010 [86], which is related to the setting of industrialization, economic development, rural socio-economic crisis, especially in dairy farming due to lower milk price and land degradation by overgrazing, which led to the rural depopulation of the Atlantic Forest, with ensuing abandonment of pastures, followed by forest regeneration [85].

This trend is also associated with reformulated decrees (e.g., Federal Decree No. 0.750 of 1993) [87], which prohibited the cutting and exploitation of disturbed forest remnants and secondary successional areas in early and advanced stages of the Atlantic Forest. In 2006, this decree was updated by Federal Law No. 0.11.428 (Atlantic Forest Law), which introduced new instruments for biome conservation, such as monetary incentives for Atlantic Forest restoration projects [88]. Along with the law, the Pact for the Restoration of the Atlantic Forest, which provides for the restoration of 15 Mha by 2050, also contributed to stabilizing the native forest area [89].

Currently, we can observe a trend of increasing losses of native forest areas due to a weakened national environmental system (SISNAMA) and changes in laws and regulations [90]. A projection made for the Atlantic Forest indicates that, if the loss of young native forests follows the current rates, we will have only 2.3 Mha of new areas by 2030 and, considering the current rate of losses of older and younger native forests, only 0.49 Mha of areas with additional native forests would be expected by 2030 [25].

Despite pasture area losses, this is still one of the main land uses of the Atlantic Forest, in which most of them are under some degradation condition [91]. Generally, there is a lack of pasture management, use of inputs, liming and fertilization [92]. Soil management through burning is still used [93]. The lack of pasture management adopted in this biome triggers high losses of soil, organic carbon, and nutrients, and these practices must be rethought to increase livestock production in these highly weathered and naturally poor soils [93].

The planted forest is a minority percentage of the territory but has gained prominence over these 35 years, with an almost five-fold growth compared to the baseline (1985). The increase in the area of planted forests occurred mainly in pasture areas due to several factors: low milk productivity and milk prices; strict distribution of state credit, mainly agricultural credit, causing producers to look for a new land use alternative; promotion of pulp and paper companies; cost-effective opportunities considering land price and distance from plantations to processing plants; conservationist ideas, such as the introduction of certification in the eucalypts production system for future fiber exports; and shortage of rural workers influenced by the demand for labor in urban centers $[85,94,95]$.

The growth of this class is still recurrent, mainly with the increase in plantations close to the pulp and paper industries [85]. Planting of eucalypts and pine stands out mainly in the south and southeast regions, while eucalypt is used for wood and bioenergy in the northeast [96].

Besides planted forests, the agriculture area almost doubled compared to 1985, which can be explained by the increase in technology and consumer market and improved rural extension program and rural credit to producers [97]. Linked to this, the domestic demand for biofuels led to the expansion of agricultural areas with sugarcane production in the Atlantic Forest [98], expanding mainly in areas of degraded pastures [30,99,100].

When we compare the map (Figure 4-Atlantic Forest) with land use in 2020 and information provided by the IBGE [101] (p. 30), we notice that the areas of most significant expansion with agricultural land (southwest and northwest) coincide with the regions 
where sugarcane plantations are concentrated. However, we should remember that the Atlantic Forest also stands out in several other cultures, such as planting wheat, rice, corn, soybeans, and coffee (south region); soybeans, citrus, cotton, corn, rice, castor beans and peanuts (southeast region); and fruit growing (northeast region) [96].

In a general context, the Atlantic Forest has suffered variations in the area with native forest for centuries. Historically, these areas are replaced mainly by agriculture and pasture areas [98]. There is a need to increase native forest areas while adopting more efficient agricultural and livestock practices so that the most populous biome in Brazil can follow a path aimed at the environmental, economic, and social fields [27,102].

\subsection{Sustainable Land Use}

Our analysis showed that areas of native forests are still being lost to other land uses. We also noticed low values of animal stocking rates, indicating inefficient systems [103]. This situation is linked with a lack of property management and often results in the abandonment of large areas [104], with the loss of native forests as a consequence [105].

This fact can be explained by the economic theory of land use proposed by Von Thünen, who mentions that the land is intended for use that gives the best economic income [106]. Thus, if the land use change and practices developed in a given area provide greater profitability, they are expected to expand at the expense of less profitable uses [107]. In this sense, the efficient use (or the intensification) generally only occurs where land is a scarce factor [108], in which the farmer will not have other opportunities.

As an example, producers seek immediate profit by associating the availability of native forest as an opportunity to expand the area with greater financial profitability. However, Brazil has enough open land to increase future agricultural production, preserving native forest lands [29], as long as it considers high productivity through intensification and sustainable land use, from the recovery of abandoned or poorly degraded pastures $[109,110]$.

Sustainable intensification aims to increase agricultural and livestock production and economic returns, per unit of time and area, minimizing negative impacts on soil and resources and the integrity of the associated non-agricultural ecosystems [34,111,112]. Until 2050 , beef production could increase by $20 \%$, crop yields by $88 \%$ and wood production by $220 \%$ in the Amazon, with the recovery and intensification of degraded and unproductive areas [113].

The diversification of plant species must occur in the intensified strategies to jointly promote environmental, social, and economic benefits $[33,110]$. Therefore, the low-carbon technology called Integrated Crop-Livestock-Forest (ICLF) reflects this scenario, as it presents livestock, agricultural, or forestry activities in the same area, in rotation, consortium, or succession, seeking synergistic effects between components, considering environmental suitability and economic feasibility [114].

It can be classified in different modalities, resulting in a several possible models, as the ones with the forest component, also called agroforestry systems: Integration CropLivestock-Forest (ICLF), or agrosilvopastoral; Integration Livestock-Forest (ILF), or silvopastoral; Integration Crop-Forest (ICF), or silvoagricultural integration; and the one without the forest component: Integration Crop-Livestock (ICL), or agropastoral [114].

The several advantages of the ICLF modalities are already well defined, such as their positive synergistic effects on the soil's physical, chemical, and biological properties that mitigate degradation compared to the exclusive land use strategies [115]. They protect the soil against erosion, mainly on slopes of the Atlantic Forest, which are subject to intense rainfall in the rainy season [116]. They also improve nutrient cycling, with uptake at greater soil depths [117] and agricultural income [118].

Pasture benefits could be even more significant, such as increasing animal support capacity [119,120] by up to $52 \%$ of its potential [29]. Increased animal production is associated with thermal comfort provided by the moderate shading of the tree component [121-123], improved annual animal weight gain, and increased forage longevity [116]. It increases land use potential and becomes an alternative to increase property revenue in the dry sea- 
son [110,121-123]. We observed a $28 \%$ increase in animal weight gain and a $23 \%$ increase in forage production [124].

This technology also can mitigate environmental impacts by increasing soil carbon stocks and reducing greenhouse gas emissions $[34,125]$. The conversion of $20 \%$ of unproductive areas in the world with ICLF strategies could potentially mitigate $3.4 \pm 1.7 \times 109 \mathrm{t}$ $\mathrm{CO}_{2}$ eq year ${ }^{-1}[126]$.

In the Amazon, greater market competitiveness, increased productivity, improved pasture, increased income, greater adaptability, and reduced risk were identified by a small portion of farmers that adopted ICLF [77]. Generally, the ICL strategy in the Amazon region is implemented from October to February in soybean cultivation in a part of the farm, while the remaining area is used for cattle maintenance. After the soybean harvest, the whole farm area is used for livestock production from March to September [127]. Adopting integrated strategies with trees is still scarce in that region, and it can occur with the afforestation of pastures with native tree species (originating from natural regeneration). However, exotic species, such as teak (Tectona grandis L.f), African-mahogany (Khaya ivorensis A. Chev.), and eucalypt (Eucalyptus sp.), are used in most cases [128].

In the Atlantic Forest, the intensification to increase income generation, diversify production, and increase the quality and productivity of the land are recognized by producers that adopt the ICLF [129]. In this biome, the ICL strategy is adopted to recover pastures and an alternative for animal feed in the restrictive period of rainfall of the year, with beans, corn, rice, sorghum, soybean, millet, and sunflower as the main crops [130]. The main species used for ICLF in that biome is also eucalypt, mainly because of its rapid growth and easy management $[130,131]$. ICLF-derived eucalypt wood is used for construction activities in the farm or sold to sawmill companies. It has a potential sequestration $\mathrm{C}$ rate of $17 \mathrm{Mg}$ $\mathrm{CO}_{2} \mathrm{eq} \mathrm{ha}{ }^{-1} \mathrm{y}^{-1}$ in its biomass [132].

A study developed by Maia et al. [133] shows that sustainable strategies have a positive impact on the Atlantic Forest when related to animal stocking rate and agricultural production per hectare, observing an increase of up to $0.5 \%$ in the mean number of animal heads per hectare in each area percentage increased with these systems. These authors did not observe significant impacts for the Amazon, justified by the predominance of extensive livestock.

Sustainable land use was encouraged by various programs and public policies over time. In the Amazon, we could mention the Action Plan for the Prevention and Control of Deforestation in the Legal Amazon (PPCDAm) [56]; Sustainable Amazon Plan [134]; Sustainable Regional Development Plan for the Area of Influence of BR 163 [135]; Public Forest Management Law [136]; Amazon Protected Areas Program (ARPA) [137]; and, more recently, Amazon Plan 2021/2022 [138]. In the Atlantic Forest, examples include Atlantic Forest Law n ${ }^{\circ} 11.428 / 2006$, including the Municipal Plan for the Conservation and Recovery of the Atlantic Forest (PMMA, 2022) [88], and Biodiversity and Climate Change Project in the Atlantic Forest [139].

At the national level, the ICLF is encouraged by public policies, such as the Low Carbon Emission Plan in Agriculture (Law n ${ }^{\circ} 12.187 / 2009$ ), which is a guideline for the use of technologies to increase agricultural productivity and promote the reduction of GHG emissions through changes in the production process [140]. Moreover, the National Crop-Livestock-Forest Integration Policy (Law n ${ }^{\circ} 12.805 / 2013$ ), which aims to improve productivity, product quality and income from agricultural activities, by implementing ICLF strategies in already deforested areas [141].

Although the ICLF is a large-scale alternative to promote the adoption of low-carbon agriculture, with all its recognized benefits of reducing the environmental impacts of food production and creating greater resilience in the food system [142], its adoption is a significant change in production techniques [21], mainly in the Amazon and Atlantic Forest, with already culturally determined land use. Thus, there are many barriers to overcome in these biomes for ICLF adoption to reach its full potential. 


\subsection{Barriers for the Adoption of ICLF Strategies in the Amazon and Atlantic Forest}

While the ICLF benefits are reported in the scientific literature, this strategy has not been widely adopted. It is projected that the four modalities of ICLF strategies in Brazil will represent 17.42 million hectares in 2020 (in all the five biomes) [143].

Looking regionally, in the Amazon and Atlantic Forest, we also notice this slow pace of adoption when we compare data from the 2006 Agricultural Census [144] and 2017 [145] of the total number of ICLF implemented.

In the Amazon biome, over these 11 years, there was a total increase of $6 \%$ in areas with ICLF, from 1.51 Mha (2006) to 1.61 Mha $(2017)[144,145]$. This represented $2.65 \%$ of the total area of pasture and agriculture (60.35 Mha-Figure 2A) in 2017. When we look at the Atlantic Forest, in the same period, the increase in new areas with ICLF implemented was $25 \%$. The ICLF, which previously occupied $1.26 \mathrm{Mha}$ (2006) in this biome, now covers 1.57 Mha (2017) of the territory [144,145], representing then $3.27 \%$ of the total area of pasture and agriculture (47.97 Mha-Figure 3A) in 2017.

Greater acceptance of sustainable systems in the Atlantic Forest may be linked to more accessible access to credit in this biome [146] and more intensive use of capital, technology, and skilled labor [133]. However, this growth is still considered low, and some studies have been carried out in order to understand the barriers behind this slow adoption process.

In the Atlantic Forest, limitations focus on uncertainty about the system, reduction in the yield of the leading agricultural crop, and lack of models and knowledge in the region [129]. Furthermore, there are bureaucratic barriers and legal uncertainties regarding the use and sale of native trees in the biome, favoring the adoption of exotic species [10,147].

As much as there is a trend towards sustainable scale-up, some producers still guide their decisions only by the transient profitability of the system, preferring conventional systems. What hampers the implementation of other systems is the lack of information and technical assistance to create a culture of sustainable production in the Atlantic Forest [8]. It is necessary to improve technical assistance, rural extension, capacity building, and training, mainly to encourage those who use conventional agriculture and successful examples to facilitate the opportunity of these producers [129].

The main barriers identified in the Amazon are related to access to credit, land tenure, infrastructure, rural education, skilled labor, and existing cultural traditions $[77,133]$. The way to use agricultural land more sustainably in the Amazon must start with improving the distribution of rural credits with competitive and sustainable credit lines; knowledge transfer, which raises awareness of high-performance technologies; direct and long-term support to producers through rural assistance and extension; and incentive through market signals $[77,148,149]$. We should highlight the importance of governmental, cultural, and ecological structures to influence the environmental perception of these producers [77].

Technologies must be available and accessible so that the ICLF is widely adopted, and this will occur through a set of strategies that will involve an integrated management process, the sustainability of the use of natural resources, finances, human resources, and the competitive market [150-152]. New Technological Reference Units (URT) must be included in strategic locations, by research centers (e.g., Embrapa), universities, and regional programs, with targeted models, to achieve these strategies. The area of influence and the profile of the target producers must be evaluated [153]. The ABC Program credits, the main line of credit for sustainable development, which includes implementing ICLF strategies, should be less bureaucratic, with adjusted interest rates, favoring their demand [154]. Besides, there is a need for greater dissemination of this credit plan between producers $[148,155]$ and training of bank managers.

It is mainly necessary to formulate policies with government actions and research institutions that incorporate environmental sustainability and organizational and technological innovations accessible with locally based initiatives [102,156,157]. 


\section{Conclusions}

In the Amazon, the expansion of pastures is still the leading cause of losing native forest areas. Agriculture has also expanded at the expense of these forests. Over the 35 years analysis (1985 to 2020), 44.53 Mha of native forests were lost so that new areas of pasture (38.10 Mha) and agriculture (6.06 Mha) emerged. Areas with planted forests are still minorities in this biome. In the Atlantic Forest, areas of 0.99 Mha of native forests and 11.53 Mha of pastures were reduced, being replaced by $8.06 \mathrm{Mha}$ of agriculture, and 2.99 Mha of planted forest.

The animal stocking rate in the pastures has increased over these years, albeit at a slow pace, which is because pastures are still extensive, without proper management, favoring soil degradation, reducing productivity, and expanding the opening of new frontiers in areas of native forest, especially in the Amazon, where this production model predominates.

These land uses are essential for economic development and food production in the country. However, they should be managed in a planned fashion, emphasizing sustainable practices. In this context, the ICLF emerges as a promising strategy, with several benefits reported in the scientific literature (e.g., increased productivity, economic viability, and environmental gains). Nevertheless, we observe that the adoption of this strategy in the Amazon and Atlantic Forest is still incipient.

Public and private policy actions should consider local and regional aspects, aiming at incentives and programs focused on adopting ICLF. In this sense, technical assistance and rural extension must be strategic in the Amazon, combined with actions to promote rural credit and regional infrastructure. In the Atlantic Forest biome, actions should be concentrated on technology transfers, aiming to reduce producers' uncertainties and the bureaucracy of laws for the sustainable use of resources/native forest species in these systems.

The approaches presented in this article reiterate the promising opportunity of the ICLF to replace exclusive uses of pastures and agriculture in conventional models. This strategy is also aligned with the ABC Plan Policies, which aim for sustainable land use to increase agricultural productivity and reduce GHG emissions.

The adoption of ICLF strategies can boost the preservation of these biomes, which have abundant natural resources. The Atlantic Forest biome has been impacted by significant losses of native forest areas over many years and currently has significant areas with low productivity, with potential for recovery and production through the implementation of these systems. The Amazon still has an immense area of native forest and can reconcile preservation with the recovery of degraded and abandoned areas, thus avoiding the setting of deforestation in the Atlantic Forest. The ICLF can strengthen the country's agriculture and economy, contributing to global food security, promoting the recovery of environments in the Atlantic Forest biome, and avoiding the devastation of the Amazon.

Author Contributions: Conceptualization, J.G.d.S., S.N.d.O.N. and R.d.A.R.R.; methodology, J.G.d.S.; formal analysis, J.G.d.S., G.C.C.S., A.C.B.d.C., F.F.G.D.L. and R.d.O.M.; investigation, J.G.d.S., A.C.B.d.C., F.F.G.D.L. and F.R.C.; data curation, J.G.d.S., G.C.C.S., A.C.B.d.C. and R.d.O.M.; writing-original draft preparation, J.G.d.S., A.C.B.d.C., F.F.G.D.L. and F.R.C.; writing-review and editing, J.G.d.S., A.C.B.d.C., F.F.G.D.L., S.N.d.O.N., R.d.A.R.R., L.T.A., I.G.M.F., M.S.L.D. and M.C.G.d.C.; visualization, J.G.d.S., S.N.d.O.N. and R.d.A.R.R.; supervision, J.G.d.S., S.N.d.O.N. and R.d.A.R.R.; project administration, S.N.d.O.N. and R.d.A.R.R. All authors have read and agreed to the published version of the manuscript.

Funding: This research is developed within the framework of the Sustainable Rural Project-Cerrado, funded by Technical Cooperation approved by the Inter-American Development Bank (IDB), with resources from the UK Government's International Climate Finance, with the Ministry of Agriculture, Livestock and Supply (MAPA) as institutional beneficiary. The Brazilian Institute for Development and Sustainability (IABS) is responsible for the execution and administration of the project and the ILPF Network Association, through Embrapa (20.21.00.090.00.00), is responsible for the scientific coordination and technical support.This research also obtained resources from the Capes, CNPq, ICLF Network and the Climate Network.

Institutional Review Board Statement: Not applicable. 
Informed Consent Statement: Not applicable.

Data Availability Statement: Not applicable.

Acknowledgments: The authors thank the Annual Mapping Project for Land Use and Land Cover in Brazil (MapBiomas) for the data used.

Conflicts of Interest: The authors declare no conflict of interest.

\section{References}

1. Luyssaert, S.; Jammet, M.; Stoy, P.C.; Estel, S.; Pongratz, J.; Ceschia, E.; Churkina, G.; Don, A.; Erb, K.; Ferlicoq, M.; et al. Land Management and Land-Cover Change Have Impacts of Similar Magnitude on Surface Temperature. Nat. Clim. Chang. 2014, 4, 389-393. [CrossRef]

2. Gomez-Zavaglia, A.; Mejuto, J.C.; Simal-Gandara, J. Mitigation of Emerging Implications of Climate Change on Food Production Systems. Food Res. Int. 2020, 134, 109256. [CrossRef] [PubMed]

3. Hertel, T.W. Food Security under Climate Change. Nat. Clim. Chang. 2016, 6, 10-13. [CrossRef]

4. United Nations. United Nations World Population Prospects 2019: Highlights; Department of Economic and Social Affairs, Population Division: New York, NY, USA, 2019; ISBN 978-92-1-148316-1.

5. Souza, C.M.; Shimbo, J.Z.; Rosa, M.R.; Parente, L.L.; Alencar, A.A.; Rudorff, B.F.T.; Hasenack, H.; Matsumoto, M.; Ferreira, L.G.; Souza-Filho, P.W.M.; et al. Reconstructing Three Decades of Land Use and Land Cover Changes in Brazilian Biomes with Landsat Archive and Earth Engine. Remote Sens. 2020, 12, 2735. [CrossRef]

6. IBGE-Instituto Brasileiro de Geografia e Estatística. Tabela 5457: Área Plantada ou Destinada à Colheita, Área Colhida, Quantidade Produzida, Rendimento Médio e Valor Da Produção Das Lavouras Temporárias e Permanentes. Available online: https:/ / sidra.ibge.gov.br/tabela/5457 (accessed on 14 September 2020).

7. IBGE-Instituto Brasileiro de Geografia e Estatística. Pesquisa Da Pecuária Municipal. Tabela 3939: Efetivo Dos Rebanhos, Por Tipo de Rebanho. Available online: https: / / sidra.ibge.gov.br/tabela/3939 (accessed on 10 January 2020).

8. Souza, C.R.; Fritz Filho, L.F.; Moretto, C.F. Os processos produtivos agrícolas na zona de amortecimento da Floresta Nacional de Passo Fundo. Rev. Econ. E Sociol. Rural. 2021, 60. [CrossRef]

9. Guedes Pinto, L.F.; Voivodic, M. Reverse the Tipping Point of the Atlantic Forest for Mitigation. Nat. Clim. Chang. 2021, 11, 364-365. [CrossRef]

10. Tubenchlak, F.; Badari, C.G.; de Freitas Strauch, G.; de Moraes, L.F.D. Changing the Agriculture Paradigm in the Brazilian Atlantic Forest: The Importance of Agroforestry. In The Atlantic Forest: History, Biodiversity, Threats and Opportunities of the Mega-Diverse Forest; Marques, M.C.M., Grelle, C.E.V., Eds.; Springer International Publishing: Cham, Switzerland, 2021; pp. 369-388; ISBN 978-3-030-55322-7.

11. Fearnside, P.M. Deforestation in Brazilian Amazonia: History, Rates, and Consequences; Instituto Nacional de Pesquisas da Amazônia (INPA): Manaus, Brazil, 2020; Volume 1, ISBN 978-85-211-0193-2.

12. Poorter, L.; van der Sande, M.T.; Thompson, J.; Arets, E.J.M.M.; Alarcón, A.; Álvarez-Sánchez, J.; Ascarrunz, N.; Balvanera, P.; Barajas-Guzmán, G.; Boit, A.; et al. Diversity Enhances Carbon Storage in Tropical Forests. Glob. Ecol. Biogeogr. 2015, 24, 1314-1328. [CrossRef]

13. Lovejoy, T.E.; Nobre, C. Amazon Tipping Point. Sci. Adv. 2018, 4, eaat2340. [CrossRef]

14. Morton, D.C.; Noojipady, P.; Macedo, M.M.; Gibbs, H.; Victoria, D.C.; Bolfe, E.L. Reevaluating Suitability Estimates Based on Dynamics of Cropland Expansion in the Brazilian Amazon. Glob. Environ. Chang. 2016, 37, 92-101. [CrossRef]

15. Meyfroidt, P.; Carlson, K.M.; Fagan, M.E.; Gutiérrez-Vélez, V.H.; Macedo, M.N.; Curran, L.M.; DeFries, R.S.; Dyer, G.A.; Gibbs, H.K.; Lambin, E.F.; et al. Multiple Pathways of Commodity Crop Expansion in Tropical Forest Landscapes. Environ. Res. Lett. 2014, 9, 074012. [CrossRef]

16. Nehren, U.; Kirchner, A.; Sattler, D.; Turetta, A.P.; Heinrich, J. Impact of Natural Climate Change and Historical Land Use on Landscape Development in the Atlantic Forest of Rio de Janeiro, Brazil. An. Acad. Bras. Ciênc. 2013, 85, 497-518. [CrossRef]

17. Scarano, F.R.; Ceotto, P. Brazilian Atlantic Forest: Impact, Vulnerability, and Adaptation to Climate Change. Biodivers. Conserv. 2015, 24, 2319-2331. [CrossRef]

18. Calmon, M.; Brancalion, P.H.S.; Paese, A.; Aronson, J.; Castro, P.; da Silva, S.C.; Rodrigues, R.R. Emerging Threats and Opportunities for Large-Scale Ecological Restoration in the Atlantic Forest of Brazil. Restor. Ecol. 2011, 19, 154-158. [CrossRef]

19. Marques, M.C.M.; Grelle, C.E.V. The Atlantic Forest: History, Biodiversity, Threats and Opportunities of the Mega-Diverse Forest; Springer Nature: Berlin, Germany, 2021; ISBN 978-3-030-55322-7.

20. Rezende, C.L.; Scarano, F.R.; Assad, E.D.; Joly, C.A.; Metzger, J.P.; Strassburg, B.B.N.; Tabarelli, M.; Fonseca, G.A.; Mittermeier, R.A. From Hotspot to Hopespot: An Opportunity for the Brazilian Atlantic Forest. Perspect. Ecol. Conserv. 2018, 16, $208-214$. [CrossRef]

21. Perosa, B.; Newton, P.; Carrer, M.J. Access to Information Affects the Adoption of Integrated Systems by Farmers in Brazil. Land Use Policy 2021, 106, 105459. [CrossRef]

22. Stabile, M.C.C.; Guimarães, A.L.; Silva, D.S.; Ribeiro, V.; Macedo, M.N.; Coe, M.T.; Pinto, E.; Moutinho, P.; Alencar, A. Solving Brazil's Land Use Puzzle: Increasing Production and Slowing Amazon Deforestation. Land Use Policy 2020, 91, 104362. [CrossRef] 
23. Ribeiro, M.C.; Metzger, J.P.; Martensen, A.C.; Ponzoni, F.J.; Hirota, M.M. The Brazilian Atlantic Forest: How Much Is Left, and How Is the Remaining Forest Distributed? Implications for Conservation. Biol. Conserv. 2009, 142, 1141-1153. [CrossRef]

24. Joly, C.A.; Metzger, J.P.; Tabarelli, M. Experiences from the Brazilian Atlantic Forest: Ecological Findings and Conservation Initiatives. New Phytol. 2014, 204, 459-473. [CrossRef]

25. Rosa, M.R.; Brancalion, P.H.S.; Crouzeilles, R.; Tambosi, L.R.; Piffer, P.R.; Lenti, F.E.B.; Hirota, M.; Santiami, E.; Metzger, J.P. Hidden Destruction of Older Forests Threatens Brazil's Atlantic Forest and Challenges Restoration Programs. Sci. Adv. 2021, 7, eabc4547. [CrossRef]

26. Lira, P.K.; Tambosi, L.R.; Ewers, R.M.; Metzger, J.P. Land-Use and Land-Cover Change in Atlantic Forest Landscapes. For. Ecol. Manag. 2012, 278, 80-89. [CrossRef]

27. Alves-Pinto, H.N.; Latawiec, A.E.; Strassburg, B.B.N.; Barros, F.S.M.; Sansevero, J.B.B.; Iribarrem, A.; Crouzeilles, R.; Lemgruber, L.; Rangel, M.C.; Silva, A.C.P. Reconciling Rural Development and Ecological Restoration: Strategies and Policy Recommendations for the Brazilian Atlantic Forest. Land Use Policy 2017, 60, 419-426. [CrossRef]

28. Câmara, G.; Soterroni, A.; Ramos, F.; Carvalho, A.; Andrade, P.; Souza, R.S.C.; Mosnier, A.; Mant, R.; Buurman, M.; Peña, M.; et al. Modelling Land Use Changes in Brazil 2000-2050: A Report by the REDD-PAC Project; HAL Open Science: Lyon, France, 2015.

29. Strassburg, B.B.N.; Latawiec, A.E.; Barioni, L.G.; Nobre, C.A.; da Silva, V.P.; Valentim, J.F.; Vianna, M.; Assad, E.D. When Enough Should Be Enough: Improving the Use of Current Agricultural Lands Could Meet Production Demands and Spare Natural Habitats in Brazil. Glob. Environ. Chang. 2014, 28, 84-97. [CrossRef]

30. Adami, M.; Rudorff, B.F.T.; Freitas, R.M.; Aguiar, D.A.; Sugawara, L.M.; Mello, M.P. Remote Sensing Time Series to Evaluate Direct Land Use Change of Recent Expanded Sugarcane Crop in Brazil. Sustainability 2012, 4, 574-585. [CrossRef]

31. Marchand, S. The Relationship between Technical Efficiency in Agriculture and Deforestation in the Brazilian Amazon. Ecol. Econ. 2012, 77, 166-175. [CrossRef]

32. Cerri, C.E.P.; Cerri, C.C.; Maia, S.M.F.; Cherubin, M.R.; Feigl, B.J.; Lal, R. Reducing Amazon Deforestation through Agricultural Intensification in the Cerrado for Advancing Food Security and Mitigating Climate Change. Sustainability 2018, 10, 989. [CrossRef]

33. Yang, Y.; Tilman, D.; Furey, G.; Lehman, C. Soil Carbon Sequestration Accelerated by Restoration of Grassland Biodiversity. Nat. Commun. 2019, 10, 718. [CrossRef] [PubMed]

34. Alves, B.J.R.; Madari, B.E.; Boddey, R.M. Integrated Crop-Livestock-Forestry Systems: Prospects for a Sustainable Agricultural Intensification. Nutr. Cycl. Agroecosyst. 2017, 108, 1-4. [CrossRef]

35. IBGE-Instituto Brasileiro de Geografia e Estatística. Biomas e Sistema Costeiro-Marinho do Brasil: Compatível Com a Escala 1:250,000; IBGE, Coordenação de Recursos Naturais e Estudos Ambientais: Rio de Janeiro, Brazil, 2019; Volume 45, ISBN 978-85-240-4510-3.

36. IBGE-Instituto Brasileiro de Geografia e Estatística. Biomas. Available online: https://www.ibge.gov.br/geociencias / cartas-emapas/informacoes-ambientais/15842-biomas.html?=\&t=downloads (accessed on 10 January 2022).

37. MapBiomas. Série Brasileira de Mapas de Cobertura e Uso da Terra: Coleções MapBiomas. Available online: https:/ /mapbiomas. org / colecoes-mapbiomas-1?cama_set_language=pt-BR (accessed on 10 January 2022).

38. MapBiomas. Accuracy Statistics-Collection 6.0. Available online: https://mapbiomas.org/accuracy-statistics?cama_set_ language=en (accessed on 13 January 2022).

39. MacDicken, K.G. Global Forest Resources Assessment 2015: What, Why and How? For. Ecol. Manag. 2015, 352, 3-8. [CrossRef]

40. IBGE-Instituto Brasileiro de Geografia e Estatística. Manuais Técnicos de Uso da Terra, 3rd ed.; Instituto Brasileiro de Geografia e Estatística-IBGE: Rio de Janeiro, Brazil, 2013; Volume 7, ISBN 978-85-240-4307-9.

41. MapBiomas. MapBiomas General "Handbook"-Algorithm Theoretical Basis Document (ATBD). Collection 6. 2022. Available online: https:/ / mapbiomas-br-site.s3.amazonaws.com/Metodologia/ATBD_Collection_6_v1_January_2022.pdf (accessed on 13 January 2022).

42. Martínez, S.; Mollicone, D. From Land Cover to Land Use: A Methodology to Assess Land Use from Remote Sensing Data. Remote Sens. 2012, 4, 1024-1045. [CrossRef]

43. De Moraes, M.C.P.; de Mello, K.; Toppa, R.H. Protected Areas and Agricultural Expansion: Biodiversity Conservation versus Economic Growth in the Southeast of Brazil. J. Environ. Manag. 2017, 188, 73-84. [CrossRef]

44. Ewert, F.; Rounsevell, M.D.A.; Reginster, I.; Metzger, M.J.; Leemans, R. Future Scenarios of European Agricultural Land Use: I. Estimating Changes in Crop Productivity. Agric. Ecosyst. Environ. 2005, 107, 101-116. [CrossRef]

45. Grassini; Eskridge, K.M.; Cassman, K.G. Distinguishing between Yield Advances and Yield Plateaus in Historical Crop Production Trends. Nat. Commun. 2013, 2918, 1-12. [CrossRef]

46. Jaiswal, R.K.; Lohani, A.K. Tiwari Statistical Analysis for Change Detection and Trend Assessment in Climatological Parameters. Environ. Process. 2015, 2, 729-749. [CrossRef]

47. Zarenistanak, M. Historical Trend Analysis and Future Projections of Precipitation from CMIP5 Models in the Alborz Mountain Area, Iran. Meteorol. Atmos. Phys. 2019, 131, 1259-1280. [CrossRef]

48. IBGE-Instituto Brasileiro de Geografia e Estatística. Pesquisas Agropecuárias-Série Relatório Metodológico; IBGE, Coordenação de Agropecuária: Rio de Janeiro, Brazil, 2018; Volume 6, ISBN 978-85-240-4450-2.

49. Domingues, S.C.O.; Silva, I.C.O.; Santos, J.S.; Yamashita, O.M.; Carvalho, M.A.C. Agricultural Activity: Legal Amazon: Ambiental Degradation. Sci. Electron. Arch. 2020, 13, 104-110. [CrossRef]

50. Fearnside, P.M. Deforestation in Brazilian Amazonia: History, Rates, and Consequences. Conserv. Biol. 2005, 19, 680-688. [CrossRef] 
51. FAO. Food Outlook—Bianual Report on Global Food Markets; FAO: Rome, Italy, 2020; ISBN 978-92-5-132848-4.

52. Börner, J.; Wunder, S.; Reimer, F.; Bakkegaard, R.K.; Viana, V.; Tezza, J.; Pinto, T.; Lima, L.; Marostica, S. Promoting Forest Stewardship in the Bolsa Floresta Programme: Local Livelihood Strategies and Preliminary Impacts; Center for International Forestry Research: Bogor Regency, Indonesia, 2013.

53. Börner, J.; Wunder, S.; Wertz-Kanounnikoff, S.; Hyman, G.; Nascimento, N. Forest Law Enforcement in the Brazilian Amazon: Costs and Income Effects. Glob. Environ. Chang. 2014, 29, 294-305. [CrossRef]

54. Börner, J.; Kis-Katos, K.; Hargrave, J.; König, K. Post-Crackdown Effectiveness of Field-Based Forest Law Enforcement in the Brazilian Amazon. PLoS ONE 2015, 10, e0121544. [CrossRef]

55. Hargrave, J.; Kis-Katos, K. Economic Causes of Deforestation in the Brazilian Amazon: A Panel Data Analysis for the 2000s. Environ. Resour. Econ. 2013, 54, 471-494. [CrossRef]

56. Brasil. Plano de Ação Para Prevenção e Controle Do Desmatamento na Amazônia Legal (PPCDAm). 2004. Available online: http:/ / redd.mma.gov.br/images/publicacoes/PPCDAM_fase1.pdf (accessed on 10 January 2022).

57. Arima, E.Y.; Barreto, P.; Araújo, E.; Soares-Filho, B. Public Policies Can Reduce Tropical Deforestation: Lessons and Challenges from Brazil. Land Use Policy 2014, 41, 465-473. [CrossRef]

58. Assunção, J.; Gandour, C.; Rocha, R.; Rocha, R. The Effect of Rural Credit on Deforestation: Evidence from the Brazilian Amazon Econ. J. 2020, 130, 290-330. [CrossRef]

59. Stropp, J.; Umbelino, B.; Correia, R.A.; Campos-Silva, J.V.; Ladle, R.J.; Malhado, A.C.M. The Ghosts of Forests Past and Future: Deforestation and Botanical Sampling in the Brazilian Amazon. Ecography 2020, 43, 979-989. [CrossRef]

60. MMA-Ministério do Meio Ambiente. Mapa de Vegetação Nativa Na Área de Aplicação Da Lei No. 11.428/2006-Lei Da Mata Atlântica (Ano Base 2009); Ministério do Meio Ambiente, Secretaria de Bidiversidade e Florestas: Brasília, Brazil, 2015.

61. Soares-Filho, B.; Moutinho, P.; Nepstad, D.; Anderson, A.; Rodrigues, H.; Garcia, R.; Dietzsch, L.; Merry, F.; Bowman, M.; Hissa, L.; et al. Role of Brazilian Amazon Protected Areas in Climate Change Mitigation. Proc. Natl. Acad. Sci. USA 2010, 107, 10821-10826. [CrossRef] [PubMed]

62. Nepstad, D.; McGrath, D.; Stickler, C.; Alencar, A.; Azevedo, A.; Swette, B.; Bezerra, T.; DiGiano, M.; Shimada, J.; Seroa da Motta, R.; et al. Slowing Amazon Deforestation through Public Policy and Interventions in Beef and Soy Supply Chains. Science 2014, 344, 1118-1123. [CrossRef]

63. Gibbs, H.K.; Munger, J.; L’Roe, J.; Barreto, P.; Pereira, R.; Christie, M.; Amaral, T.; Walker, N.F. Did Ranchers and Slaughterhouses Respond to Zero-Deforestation Agreements in the Brazilian Amazon? Conserv. Lett. 2016, 9, 32-42. [CrossRef]

64. Carvalho, R.; Adami, M.; Amaral, S.; Bezerra, F.G.; de Aguiar, A.P.D. Changes in Secondary Vegetation Dynamics in a Context of Decreasing Deforestation Rates in Pará, Brazilian Amazon. Appl. Geogr. 2019, 106, 40-49. [CrossRef]

65. Azevedo Junior, W.C.; Rodrigues, M.; Silva, D.C.C. Does Agricultural Efficiency Contribute to Slowdown of Deforestation in the Brazilian Legal Amazon? J. Nat. Conserv. 2022, 65, 126092. [CrossRef]

66. Tollefson, J. Brazil's Presidential Election Could Savage Its Science. Nature 2018, 562, 171-173. [CrossRef]

67. Abessa, D.; Famá, A.; Buruaem, L. The Systematic Dismantling of Brazilian Environmental Laws Risks Losses on All Fronts. Nat. Ecol. Evol. 2019, 3, 510-511. [CrossRef]

68. Rajão, R.; Soares-Filho, B.; Nunes, F.; Börner, J.; Machado, L.; Assis, D.; Oliveira, A.; Pinto, L.; Ribeiro, V.; Rausch, L.; et al. The Rotten Apples of Brazil's Agribusiness. Science 2020, 369, 246-248. [CrossRef]

69. Fearnside, P.M. Retrocessos Sob o Presidente Bolsonaro: Um Desafio à Sustentabilidade Na Amazônia. Sustentabilidade Int. Sci. J. 2019, 1, 38-52.

70. Araújo, R.; Vieira, I. Desmatamento e as Ideologias Da Expansão Da Fronteira Agrícola: O Caso Das Críticas Ao Sistema de Monitoramento Da Floresta Amazônica. Sustain. Debate 2019, 10, 366-378.

71. Amaral, D.F.; de Souza Ferreira Filho, J.B.; Chagas, A.L.S.; Adami, M. Expansion of Soybean Farming into Deforested Areas in the Amazon Biome: The Role and Impact of the Soy Moratorium. Sustain. Sci. 2021, 16, 1295-1312. [CrossRef]

72. Schielein, J.; Ponzoni Frey, G.; Miranda, J.; de Souza, R.A.; Boerner, J.; Henderson, J. The Role of Accessibility for Land Use and Land Cover Change in the Brazilian Amazon. Appl. Geogr. 2021, 132, 102419. [CrossRef]

73. McArthur, J.W.; McCord, G.C. Fertilizing Growth: Agricultural Inputs and Their Effects in Economic Development. J. Dev. Econ. 2017, 127, 133-152. [CrossRef]

74. Richards, P.D.; Walker, R.T.; Arima, E.Y. Spatially Complex Land Change: The Indirect Effect of Brazil's Agricultural Sector on Land Use in Amazonia. Glob. Environ. Chang. 2014, 29, 1-9. [CrossRef]

75. Garrett, R.D.; Gardner, T.A.; Morello, T.F.; Marchand, S.; Barlow, J.; de Blas, D.E.; Ferreira, J.; Lees, A.C.; Parry, L. Explaining the Persistence of Low Income and Environmentally Degrading Land Uses in the Brazilian Amazon. Ecol. Soc. 2017, 22, 27. [CrossRef]

76. Barbosa, F.A.; Soares Filho, B.S.; Merry, F.D.; Azevedo, H.D.O.; Costa, W.L.S.; Coe, M.T.; Batista, E.D.S.; Maciel, T.; Sheepers, L.; de Oliveira, A.; et al. Cenários Para a Pecuária de Corte Amazônica; Universidade Federal de Minas Gerais: Belo Horizonte, Brazil, 2015; p. 146.

77. Cortner, O.; Garrett, R.D.; Valentim, J.F.; Ferreira, J.; Niles, M.T.; Reis, J.; Gil, J. Perceptions of Integrated Crop-Livestock Systems for Sustainable Intensification in the Brazilian Amazon. Land Use Policy 2019, 82, 841-853. [CrossRef]

78. Rada, N.; Helfand, S.; Magalhães, M. Agricultural Productivity Growth in Brazil: Large and Small Farms Excel. Food Policy 2019, 84, 176-185. [CrossRef] 
79. Garrett, R.D.; Cammelli, F.; Ferreira, J.; Levy, S.A.; Valentim, J.; Vieira, I. Forests and Sustainable Development in the Brazilian Amazon: History, Trends, and Future Prospects. Annu. Rev. Environ. Resour. 2021, 46, 625-652. [CrossRef]

80. Merry, F.; Soares-Filho, B. Will Intensification of Beef Production Deliver Conservation Outcomes in the Brazilian Amazon? Elem. Sci. Anthr. 2017, 5, 24. [CrossRef]

81. Teixeira, A.M.G.; Soares-Filho, B.S.; Freitas, S.R.; Metzger, J.P. Modeling Landscape Dynamics in an Atlantic Rainforest Region: Implications for Conservation. For. Ecol. Manag. 2009, 257, 1219-1230. [CrossRef]

82. Bernard, E.; Melo, F.P.L.; Pinto, S.R.R. Desafios e Oportunidades Para a Conservação Da Biodiversidade Na Mata Atlântica Frente à Expansão Do Bioetanol. Trop. Conserv. Sci. 2011, 4, 267-275. [CrossRef]

83. Pádua, J.A. A Mata Atlântica e a Floresta Amazônica na construção do território brasileiro: Estabelecendo um marco de análise. Rev. História Reg. 2015, 20, 16. [CrossRef]

84. Britto, F.R.A.; de Oliveira, A.M.H.C.; Caetano, A.J. A Ocupação Do Território e a Devastação Da Mata Atlântica. In Biodiversidade, População e Economia: Uma Região de Mata Atlântica [Biodiversity, Population and Economy: A Region of Atlantic Forest]; Cedeplar, Universidade Federal de Minas Gerais: Belo Horizonte, Brazil, 1997; pp. 49-89.

85. Da Silva, R.F.B.; Batistella, M.; Moran, E.F. Socioeconomic Changes and Environmental Policies as Dimensions of Regional Land Transitions in the Atlantic Forest, Brazil. Environ. Sci. Policy 2017, 74, 14-22. [CrossRef]

86. Silva, R.F.B.; Batistella, M.; Moran, E.F.; Lu, D. Land Changes Fostering Atlantic Forest Transition in Brazil: Evidence from the Paraíba Valley. Prof. Geogr. 2017, 69, 80-93. [CrossRef]

87. Brasil. Decreto No 750, de 10 de Fevereiro de 1993-Dispõe Sobre o Corte, a Exploração e a Supressão de Vegetação Primária Ou Nos Estágios Avançado e Médio de Regeneração Da Mata Atlântica. 1993. Available online: http:/ / www.planalto.gov.br/ccivil_ 03/decreto/1990-1994/d750.htm (accessed on 26 January 2022).

88. Brasil. Lei No 11.428, de 22 de Dezembro de 2006—Lei Da Mata Atlântica. 2006. Available online: http:/ / www.planalto.gov.br/ ccivil_03/_ato2004-2006/2006/lei/111428.htm (accessed on 26 January 2022).

89. Rodrigues, R.R.; Padovezi, A.; Farah, F.T.; Garcia, L.C.; Sanglade, L.C.; Brancalion, P.H.S.; Chaves, R.B.; Viani, R.A.G.; Barreto, T.E. Pacto Pela Restauração Da Mata Atlântica—Protocolo de Monitoramento Para Programas e Projetos de Restauração Florestal. 2013. Available online: https:/ / pactomataatlantica.org.br/wp-content/uploads/2021/05/protocolo-de-monitoramento-pt.pdf (accessed on 26 January 2022).

90. Faria, V.G.; de Mello, K.; Pinto, L.F.G.; Brites, A.; Tavares, P.A.; Fernandes, R.B.; Chamma, A.L.S.; Fransozi, A.A.; del Giudice, R.; Rosa, M.; et al. O Código Florestal Na Mata Atlântica. Sustain. Debate 2021. [CrossRef]

91. Nogueira, L.R.; Silva, C.F.D.; Pereira, M.G.; Gaia-Gomes, J.H.; Silva, E.M.R.D. Biological Properties and Organic Matter Dynamics of Soil in Pasture and Natural Regeneration Areas in the Atlantic Forest Biome. Rev. Bras. Ciênc. Solo 2016, 40. [CrossRef]

92. Bertossi, A.P.A.; Da Rocha Junior, P.R.; Ribeiro, P.H.; Menezes, J.P.C.D.; Cecílio, R.A.; Andrade, F.V. Soil Cover and Chemical and Physical Attributes in Oxisol in the Atlantic Forest Biome. Rev. Árvore 2016, 40, 219-228. [CrossRef]

93. Da Rocha Junior, P.R.; Andrade, F.V.; de Sá Mendonça, E.; Donagemma, G.K.; Fernandes, R.B.A.; Bhattharai, R.; Kalita, P.K. Soil, Water, and Nutrient Losses from Management Alternatives for Degraded Pasture in Brazilian Atlantic Rainforest Biome. Sci. Total Environ. 2017, 583, 53-63. [CrossRef]

94. Queiroz, L.D.S.; Barrichelo, L. A Celulose de Eucalipto: Uma Oportunidade Brasileira; Avis Brasilis Editora: Vinhedo, Brazil, 2008.

95. Da Silva, R.F.B.; Batistella, M.; Moran, E.F. Drivers of Land Change: Human-Environment Interactions and the Atlantic Forest Transition in the Paraíba Valley, Brazil. Land Use Policy 2016, 58, 133-144. [CrossRef]

96. Embrapa ILPF. Biomas Mata Atlântica-Portal Embrapa. Available online: https://www.embrapa.br/web/rede-ilpf/bioma/ mata-atlantica\#this (accessed on 26 January 2022).

97. Brannstrom, C. Conservation-with-Development Models in Brazil's Agro-Pastoral Landscapes. World Dev. 2001, $29,1345-1359$. [CrossRef]

98. Silva, A.L.; Salas Alves, D.; Pinheiro Ferreira, M. Landsat-Based Land Use Change Assessment in the Brazilian Atlantic Forest: Forest Transition and Sugarcane Expansion. Remote Sens. 2018, 10, 996. [CrossRef]

99. Ferreira, M.P.; Alves, D.S.; Shimabukuro, Y.E. Forest Dynamics and Land-Use Transitions in the Brazilian Atlantic Forest: The Case of Sugarcane Expansion. Reg. Environ. Chang. 2015, 15, 365-377. [CrossRef]

100. Alkimim, A.; Clarke, K.C. Land Use Change and the Carbon Debt for Sugarcane Ethanol Production in Brazil. Land Use Policy 2018, 72, 65-73. [CrossRef]

101. IBGE-Instituto Brasileiro de Geografia e Estatística. A Geografia Da Cana-de-Açúcar, Dinâmica Territorial Da Produção Agropecuária; IBGE: Rio de Janeiro, Brazil, 2017; ISBN 978-85-240-4443-4.

102. Crouzeilles, R.; Santiami, E.; Rosa, M.; Pugliese, L.; Brancalion, P.H.S.; Rodrigues, R.R.; Metzger, J.P.; Calmon, M.; Scaramuzza, C.A.D.M.; Matsumoto, M.H.; et al. There Is Hope for Achieving Ambitious Atlantic Forest Restoration Commitments. Perspect. Ecol. Conserv. 2019, 17, 80-83. [CrossRef]

103. Lapola, D.M.; Martinelli, L.A.; Peres, C.A.; Ometto, J.P.H.B.; Ferreira, M.E.; Nobre, C.A.; Aguiar, A.P.D.; Bustamante, M.M.C.; Cardoso, M.F.; Costa, M.H.; et al. Pervasive Transition of the Brazilian Land-Use System. Nat. Clim. Chang. 2014, 4, 27-35. [CrossRef]

104. Kaimowitz, D.; Angelsen, A. Will Livestock Intensification Help Save Latin America's Tropical Forests? J. Sustain. For. 2008, 27, 6-24. [CrossRef] 
105. Garcia, E.; Ramos Filho, F.S.V.; Mallmann, G.M.; Fonseca, F. Costs, Benefits and Challenges of Sustainable Livestock Intensification in a Major Deforestation Frontier in the Brazilian Amazon. Sustainability 2017, 9, 158. [CrossRef]

106. Von Thünen, J.H. Thunen's Isolated State: An English Edition of Der Isolierte Staat; Hall, P., Ed.; Pergamon Press: Oxford, UK, 1826.

107. Barretto, A.G.O.P.; Berndes, G.; Sparovek, G.; Wirsenius, S. Agricultural Intensification in Brazil and Its Effects on Land-Use Patterns: An Analysis of the 1975-2006 Period. Glob. Chang. Biol. 2013, 19, 1804-1815. [CrossRef]

108. Villoria, N.B.; Byerlee, D.; Stevenson, J. The Effects of Agricultural Technological Progress on Deforestation: What Do We Really Know? Appl. Econ. Perspect. Policy 2014, 36, 211-237. [CrossRef]

109. Foley, J.A.; DeFries, R.; Asner, G.P.; Barford, C.; Bonan, G.; Carpenter, S.R.; Chapin, F.S.; Coe, M.T.; Daily, G.C.; Gibbs, H.K.; et al. Global Consequences of Land Use. Science 2005, 309, 570-574. [CrossRef] [PubMed]

110. Magalhães, C.A.S.; Pedreira, B.C.; Tonini, H.; Farias Neto, A.L. Crop, Livestock and Forestry Performance Assessment under Different Production Systems in the North of Mato Grosso, Brazil. Agrofor. Syst. 2019, 93, 2085-2096. [CrossRef]

111. Vilela, L.; Martha Junior, G.B.; Macedo, M.C.M.; Marchão, R.L.; Guimarães Júnior, R.; Pulrolnik, K.; Maciel, G.A. Sistemas de integração lavoura-pecuária na região do Cerrado. Pesqui. Agropecu. Bras. 2011, 46, 1127-1138. [CrossRef]

112. Pretty, J.; Bharucha, Z.P. Sustainable intensification in agricultural systems. Ann. Bot. 2014, 114, 1571-1596. [CrossRef] [PubMed]

113. Rovere, E.L.L.; Wills, W.; Grottera, C.; Dubeux, C.B.S.; Gesteira, C. Economic and Social Implications of Low-Emission Development Pathways in Brazil. Carbon Manag. 2018, 9, 563-574. [CrossRef]

114. Balbino, L.C.; Barcellos, A.D.O.; Stone, L.F. Marco Referencial: Integração Lavoura-Pecuária-Floresta = Reference Document CropLivestock-Forestry Integration, 1st ed.; Embrapa: Brasília, Brazil, 2011.

115. Lemaire, G.; Franzluebbers, A.; de Faccio Carvalho, P.C.; Dedieu, B. Integrated Crop-Livestock Systems: Strategies to Achieve Synergy between Agricultural Production and Environmental Quality. Agric. Ecosyst. Environ. 2014, 190, 4-8. [CrossRef]

116. Xavier, D.F.; da Silva Lédo, F.J.; Paciullo, D.S.; Urquiaga, S.; Alves, B.J.R.; Boddey, R.M. Nitrogen Cycling in a Brachiaria-Based Silvopastoral System in the Atlantic Forest Region of Minas Gerais, Brazil. Nutr. Cycl. Agroecosyst. 2014, 99, 45-62. [CrossRef]

117. Franzluebbers, A.J.; Chappell, J.C.; Shi, W.; Cubbage, F.W. Greenhouse Gas Emissions in an Agroforestry System of the Southeastern USA. Nutr. Cycl. Agroecosyst. 2017, 108, 85-100. [CrossRef]

118. Moraes, A.; de Faccio Carvalho, P.C.; Anghinoni, I.; Lustosa, S.B.C.; de Andrade, S.E.V.G.; Kunrath, T.R. Integrated Crop-Livestock Systems in the Brazilian Subtropics. Eur. J. Agron. 2014, 57, 4-9. [CrossRef]

119. Borges, W.L.B.; Calonego, J.C.; Rosolem, C.A. Impact of Crop-Livestock-Forest Integration on Soil Quality. Agrofor. Syst. 2019, 93, 2111-2119. [CrossRef]

120. Domiciano, L.F.; Mombach, M.A.; Carvalho, P.; da Silva, N.M.F.; Pereira, D.H.; Cabral, L.S.; Lopes, L.B.; Pedreira, B.C. Performance and Behaviour of Nellore Steers on Integrated Systems. Anim. Prod. Sci. 2018, 58, 920-929. [CrossRef]

121. Baliscei, M.A.; Barbosa, O.R.; Souza, W.D.; Costa, M.A.T.; Krutzmann, A.; Queiroz, E.D.O. Microclimate without Shade and Silvopastoral System during Summer and Winter. Acta Sci. Anim. Sci. 2013, 35, 49-56. [CrossRef]

122. Lima, M.A.; Paciullo, D.S.C.; Morenz, M.J.F.; Gomide, C.A.M.; Rodrigues, R.A.R.; Chizzotti, F.H.M. Productivity and Nutritive Value of Brachiaria Decumbens and Performance of Dairy Heifers in a Long-Term Silvopastoral System. Grass Forage Sci. 2019, 74, 160-170. [CrossRef]

123. Paciullo, D.S.C.; de Castro, C.R.T.; de Miranda Gomide, C.A.; Maurício, R.M.; Pires, M.D.F.Á.; Müller, M.D.; Xavier, D.F. Performance of Dairy Heifers in a Silvopastoral System. Livest. Sci. 2011, 141, 166-172. [CrossRef]

124. De Carvalho, P.; Domiciano, L.F.; Mombach, M.A.; do Nascimento, H.L.B.; Cabral, L.D.S.; Sollenberger, L.E.; Pereira, D.H.; Pedreira, B.C. Forage and Animal Production on Palisadegrass Pastures Growing in Monoculture or as a Component of Integrated Crop-Livestock-Forestry Systems. Grass Forage Sci. 2019, 74, 650-660. [CrossRef]

125. Oliveira Resende, L.; Müller, M.D.; Kohmann, M.M.; Pinto, L.F.G.; Junior, L.C.; de Zen, S.; Rego, L.F.G. Silvopastoral Management of Beef Cattle Production for Neutralizing the Environmental Impact of Enteric Methane Emission. Agrofor. Syst. 2020, 94, 893-903. [CrossRef]

126. Kim, D.-G.; Kirschbaum, M.U.F.; Beedy, T.L. Carbon Sequestration and Net Emissions of CH4 and N2O under Agroforestry: Synthesizing Available Data and Suggestions for Future Studies. Agric. Ecosyst. Environ. 2016, 226, 65-78. [CrossRef]

127. Reis, J.C.; Rodrigues, G.S.; de Barros, I.; Rodrigues, R.D.A.R.; Garrett, R.D.; Valentim, J.F.; Kamoi, M.Y.T.; Michetti, M.; Wruck, F.J.; Rodrigues-Filho, S.; et al. Integrated Crop-Livestock Systems: A Sustainable Land-Use Alternative for Food Production in the Brazilian Cerrado and Amazon. J. Clean. Prod. 2021, 283, 124580. [CrossRef]

128. Martínez, G.B.; Botelho, F.J.E.; Bendahan, A.B.; De Moraes, A.J.G.; Silva, A.R.; Godinho, V.P.C.; Medeiros, R.D.; Oliveira, T.K.; Franke, I.L.; Perin, R.; et al. Sistemas ILPF e Transferência de Tecnologia Nos Estados Do Acre, Amazonas, Amapá, Pará, Rondônia e Roraima. In Sistemas de Integração Lavoura-Pecuária-Floresta no Brasil-Estratégias Regionais de Transferência de Tecnologia, Avaliação da Adoção e de Impactos; Skorupa, L.A., Manzatto, C.V., Eds.; Chapter 2; Embrapa: Brasília, Brazil, 2019.

129. Sagastuy, M.; Krause, T. Agroforestry as a Biodiversity Conservation Tool in the Atlantic Forest? Motivations and Limitations for Small-Scale Farmers to Implement Agroforestry Systems in North-Eastern Brazil. Sustainability 2019, 11, 6932. [CrossRef]

130. Santana, D.P.; Noce, M.A.; Borghi, E.; Alvarenga, R.C.; Neto, A.R.; Muller, M.D.; Martins, C.E.; Bernardo, W.F.; Viana, M.C.M.; Pires, J.A.A.; et al. Sistemas ILPF e Transferência de Tecnologia Nos Estados de Minas Gerais, Espírito Santo e Rio de Janeiro. In Sistemas de Integração Lavoura-Pecuária-Floresta no Brasil-Estratégias Regionais de Transferência de Tecnologia, Avaliação da Adoção e de Impactos; Skorupa, L.A., Manzatto, C.V., Eds.; Chapter 6; Embrapa: Brasília, Brazil, 2019. 
131. Castro, C.A.D.O.; Resende, R.T.; Bhering, L.L.; Cruz, C.D. Brief History of Eucalyptus Breeding in Brazil under Perspective of Biometric Advances. Ciênc. Rural 2016, 46, 1585-1593. [CrossRef]

132. De Figueiredo, E.B.; Jayasundara, S.; de Oliveira Bordonal, R.; Berchielli, T.T.; Reis, R.A.; Wagner-Riddle, C.; La Scala, N., Jr. Greenhouse Gas Balance and Carbon Footprint of Beef Cattle in Three Contrasting Pasture-Management Systems in Brazil. J. Clean. Prod. 2017, 142, 420-431. [CrossRef]

133. Maia, A.G.; dos Santos Eusebio, G.; Fasiaben, M.D.C.R.; Moraes, A.S.; Assad, E.D.; Pugliero, V.S. The Economic Impacts of the Diffusion of Agroforestry in Brazil. Land Use Policy 2021, 108, 105489. [CrossRef]

134. Brasil. Plano Amazônia Sustentável: Diretrizes Para o Desenvolvimento Sustentável Da Amazônia Brasileira; Ministério do Meio Ambiente: Secretaria de Políticas de Desenvolvimento Regional. 2008. Available online: http://www.fundoamazonia.gov.br/ export/sites/default/pt/.galleries/documentos/biblioteca/PAS-Presidencia-Republica.pdf (accessed on 26 January 2022).

135. Brasil. Decreto No 6.290, de 6 de Dezembro de 2007-Institui o Plano de Desenvolvimento Regional Sustentável Para a Área de Influência Da Rodovia BR-163 No Trecho Cuiabá/MT—Santarém/PA—Plano BR-163 Sustentável, e Dá Outras Providências. 2007. Available online: http:/ /www.planalto.gov.br/ccivil_03/_ato2007-2010/2007/decreto/d6290.htm (accessed on 18 January 2022).

136. Brasil. Lei No 11.284, de 2 de Março de 2006-Gestão de Florestas Públicas Para a Produção Sustentável. 2006. Available online: http:/ /www.planalto.gov.br/ccivil_03/_ato2004-2006/2006/lei/111284.htm (accessed on 18 January 2022).

137. Brasil. Decreto No 8.505, de 20 de Agorsto de 2015-Dispõe Sobre o Programa Áreas Protegidas Da Amazônia, Instituído No Âmbito Do Ministério Do Meio Ambiente. 2015. Available online: http://www.planalto.gov.br/ccivil_03/_ato2015-2018/2015/ decreto/d8505.htm. (accessed on 18 January 2022).

138. Brasil. Resolução no 3 de 9 de Abril de 2021—Plano Amazônia 2021/2022. 2021. Available online: https://www.in.gov.br/web/ dou (accessed on 10 January 2022).

139. Brasil. Projeto Biodiversidade e Mudanças Climáticas na Mata Atlântica. Available online: https://antigo.mma.gov.br/areasprotegidas/programas-e-projetos/projeto-mata-atl\%C3\%A2ntica.html (accessed on 26 January 2022).

140. Brasil. Lei No 12.187, de 29 de Dezembro de 2009. Política Nacional Sobre Mudança do Clima. 2009. Available online: http:/ / www.planalto.gov.br/ccivil_03/_ato2007-2010/2009/lei/112187.htmhttp://www.planalto.gov.br/ccivil_03/_ato20072010/2009/lei/112187.htm (accessed on 26 January 2022).

141. Brasil. Lei No 12.805, de 29 de Abril de 2013. Institui a Política Nacional de Integração. Lavoura-Pecuária-Floresta e Altera a Lei No 8.171, de 17 de Janeiro de 1991. 2013. Available online: http://www.planalto.gov.br/ccivil_03/_ato2011-2014/2013/lei/1128 05.htm (accessed on 13 January 2022).

142. Brasil. Plano Setorial de Mitigação e de Adaptação Às Mudanças Climáticas Para a Consolidação de Uma Economia de Baixa Emissão de Carbono Na Agricultura, 1st ed.; Ministério da Agricultura, Pecuária e Abastecimento, Ministério do Desenvolvimento Agrário, Coordenação da Casa Civil da Presidência da República-Brasília: MAPA/ACS: Brasília, Brasil, 2012; ISBN 978-85-7991-062-0.

143. Polidoro, J.C.; de Freitas, P.L.; Hernani, L.C.; Anjos, L.H.C.D.; Rodrigues, R.D.A.R.; Cesário, F.V.; Andrade, A.G.D.; Ribeiro, J.L. Potential Impact of Plans and Policies Based on the Principles of Conservation Agriculture on the Control of Soil Erosion in Brazil. Land Degrad. Dev. 2021, 32, 3457-3468. [CrossRef]

144. IBGE-Instituto Brasileiro de Geografia e Estatística. Tabela 1112—Número de Estabelecimentos Agropecuários e Área Dos Estabelecimentos Por Utilização Das Terras e Agricultura Familiar. Available online: https://sidra.ibge.gov.br/tabela/1112 \#notas-tabela (accessed on 10 January 2022).

145. IBGE-Instituto Brasileiro de Geografia e Estatística. Tabela 6881-Número de Estabelecimentos Agropecuários Com Área e Área Dos Estabelecimentos Agropecuários, Por Tipologia, Utilização Das Terras, Condição Do Produtor Em Relação Às Terras, Grupos de Atividade Econômica e Origem Da Orientação Técnica Recebida. Available online: https://sidra.ibge.gov.br/tabela/6881 (accessed on 10 January 2022).

146. Dos Santos Eusébio, G.; Maia, A.G.; da Silveira, R.L.F. CRÉDITO RURAL E IMPACTO SOBRE O VALOR DA PRODUÇÃO AGROPECUÁRIA: Uma análise para agricultores não familiares. Gest. Reg. 2020, 36. [CrossRef]

147. Urruth, L.M.; Bassi, J.B.; Chemello, D. Policies to Encourage Agroforestry in the Southern Atlantic Forest. Land Use Policy 2022, 112, 105802. [CrossRef]

148. Zu Ermgassen, E.K.H.J.; Alcântara, M.P.D.; Balmford, A.; Barioni, L.; Neto, F.B.; Bettarello, M.M.F.; Brito, G.D.; Carrero, G.C.; Florence, E.D.A.S.; Garcia, E.; et al. Results from On-The-Ground Efforts to Promote Sustainable Cattle Ranching in the Brazilian Amazon. Sustainability 2018, 10, 1301. [CrossRef]

149. Carrer, M.J.; Maia, A.G.; de Mello Brandão Vinholis, M.; de Souza Filho, H.M. Assessing the Effectiveness of Rural Credit Policy on the Adoption of Integrated Crop-Livestock Systems in Brazil. Land Use Policy 2020, 92, 104468. [CrossRef]

150. Dill, M.D.; Emvalomatis, G.; Saatkamp, H.; Rossi, J.A.; Pereira, G.R.; Barcellos, J.O.J. Factors Affecting Adoption of Economic Management Practices in Beef Cattle Production in Rio Grande Do Sul State, Brazil. J. Rural Stud. 2015, 42, 21-28. [CrossRef]

151. Kay, R.D.; Edwards, W.M.; Duffy, P.A. Gestão de Propriedades Rurais, 7th ed.; AMGH: Porto Alegre, Brazil, 2014; ISBN 978-85-8055-395-6.

152. Tavernier, E.M.; Onyango, B.M. Utilization of Farm Management Risk Strategies at the Rural/Urban Fringe. Afr. J. Agric. Res. 2008, 3, 554-565. [CrossRef]

153. Skorupa, L.A.; Manzatto, C.V. Avaliação da Adoção de Sistemas de Integração Lavoura-Pecuária-Floresta (ILPF) no Brasil. In Sistemas de Integração Lavoura-Pecuária-Floresta no Brasil: Estratégias Regionais de Transferência de Tecnologia, Avaliação da Adoção e de Impactos; Embrapa: Brasília, Brazil, 2019. 
154. Lopes, D.; Lowery, S. Rural Credit in Brazil: Challenges and Opportunities for Promoting Sustainable Agriculture; 2015. Available online: https:/ / www.forest-trends.org/wp-content/uploads/imported/ft-mapping-rural-credit-in-brazil_v19_final-rev-pdf. pdf (accessed on 13 January 2022).

155. Observatório ABC. Desafios e Restrições Dos Produtores Rurais Na Adoção de Tecnologias de Baixo Carbono ABC; 2017. Available online: http:/ / observatorioabc.com.br/wp-content/uploads/2017/05/Sumario_ABC_AltaFloresta_-1.pdf (accessed on 13 January 2022).

156. Pereira, E.J.D.A.L.; de Santana Ribeiro, L.C.; da Silva Freitas, L.F.; de Barros Pereira, H.B. Brazilian Policy and Agribusiness Damage the Amazon Rainforest. Land Use Policy 2020, 92, 104491. [CrossRef]

157. Strassburg, B.B.N. Conservation Provides Multiple Wins for Brazil. Nat. Ecol. Evol. 2019, 3, 508-509. [CrossRef] [PubMed] 